\title{
The Bahamas: 2007 Article IV Consultation-Staff Report and Public Information Notice on the Executive Board Discussion
}

Under Article IV of the IMF's Articles of Agreement, the IMF holds bilateral discussions with members, usually every year. In the context of the 2007 Article IV consultation with The Bahamas, the following documents have been released and are included in this package:

- the staff report for the 2007 Article IV consultation, prepared by a staff team of the IMF, following discussions that ended on September 20, 2007, with the officials of The Bahamas on economic developments and policies. Based on information available at the time of these discussions, the staff report was completed on November 9, 2007. The views expressed in the staff report are those of the staff team and do not necessarily reflect the views of the Executive Board of the IMF.

- a Public Information Notice (PIN) summarizing the views of the Executive Board as expressed during its November 26, 2007 discussion of the staff report that concluded the Article IV consultation.

The policy of publication of staff reports and other documents allows for the deletion of market-sensitive information.

To assist the IMF in evaluating the publication policy, reader comments are invited and may be sent by e-mail to publicationpolicy@imf.org.

\author{
Copies of this report are available to the public from \\ International Monetary Fund • Publication Services \\ $70019^{\text {th }}$ Street, N.W. • Washington, D.C. 20431 \\ Telephone: (202) 623-7430 • Telefax: (202) 623-7201 \\ E-mail: publications@imf.org Internet: http://www.imf.org
}

Price: $\$ 18.00$ a copy

\section{International Monetary Fund Washington, D.C.}





\title{
INTERNATIONAL MONETARY FUND
}

\author{
THE BAHAMAS
}

\section{Staff Report for the 2007 Article IV Consultation}

\author{
Prepared by the Staff Representatives for the 2007 \\ Article IV Consultation with The Bahamas
}

Approved by Markus Rodlauer and Scott Brown

November 9, 2007

\section{Executive Summary}

Background. Real GDP grew by $3 \frac{1}{2}$ percent in 2006, supported by buoyant construction on new resort and second-home projects, contributing to a sharp reduction in the unemployment rate. Tourism arrivals declined mainly due to the recovery of competitors from hurricane damage and new U.S. travel regulations. A sharp increase in the current account deficit to over 25 percent of GDP, reflected imports related to hotel projects financed mainly by foreign direct investment. Inflation remains low ( $2-2 \frac{1}{2}$ percent) reflecting the exchange rate peg to the U.S. dollar. The fiscal accounts deteriorated in FY 2006/07, mainly because of one-off factors, but both the deficit (2 $1 / 2$ percent of GDP) and public debt (41 percent of GDP) are relatively low and are not a source of significant vulnerability for the economy.

Outlook and Risks. Growth is projected to rebound next year based on the expectation that tourist activity will recover as new and upgraded facilities come on stream. However, this recovery may be tempered if U.S. economic activity turns out to be weaker than currently projected. Medium-term prospects are favorable and consistent with continuing external stability, based on strong investment in tourism capacity, and the sound macroeconomic policy framework. However, a very competitive regional tourism market, high oil prices, and vulnerability to hurricanes may pose challenges.

Focus of Discussions: Policies to maintain macroeconomic stability and enhance overall efficiency.

- Fiscal policy. The government's goals of balancing the budget and reducing debt to 30-35 percent of GDP by 2012 are well placed. The authorities agreed that to achieve the targets, it will be important to restrain the growth of recurrent primary spending which has expanded at a rapid pace in recent years.

- Monetary policy. Staff recommended to bolster the stock of international reserves by moderating the growth of credit. While the current level of international reserves ( 80 percent of base money) is not an immediate cause for concern, it is below the central bank's own benchmark of 100 percent of base money, and the planned gradual further easing of capital controls warrants an additional precautionary cushion. The authorities are closely monitoring the situation and stand ready to take whatever measures necessary safeguard the reserve position and the currency peg.

- Reforms. Staff endorsed the authorities' plan to move toward market-oriented instruments of monetary policy (Fund TA has been provided). The further relaxation of exchange controls, managed carefully as intended by the authorities, will contribute to capital market development and economic efficiency. 
Executive Summary 1

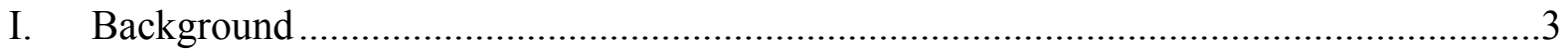

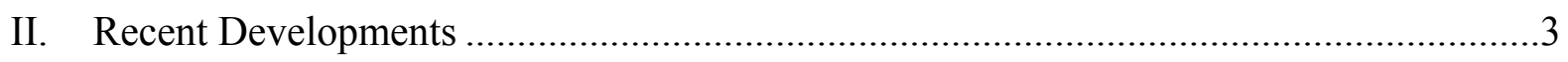

III. Outlook for 2007-08 and the Medium Term ......................................................11

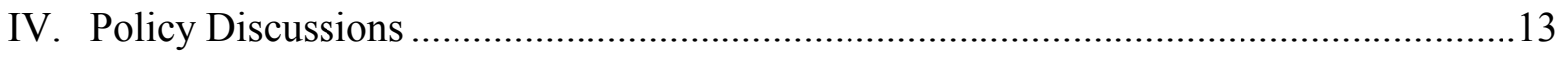

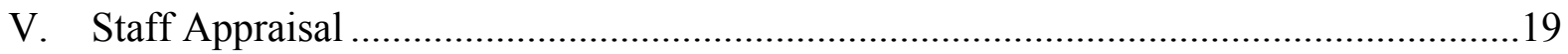

Box

1. The Introduction of Indirect Instruments of Monetary Policy ................................... 17

Figures

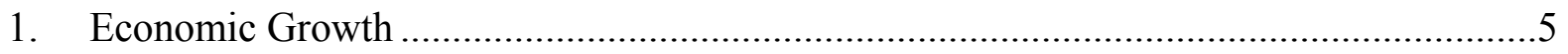

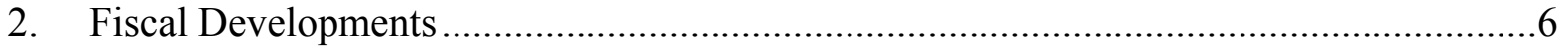

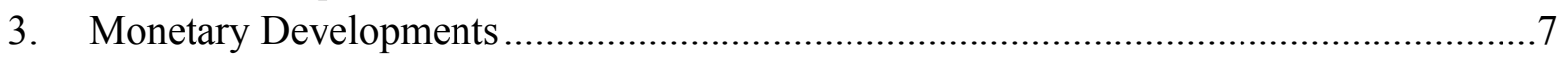

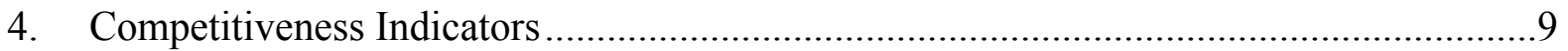

Tables

1. Selected Economic Indicators ................................................................................22

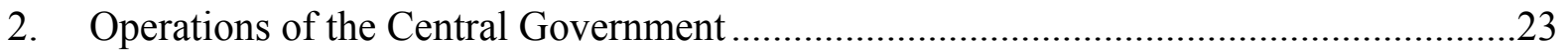

3. Operations of the Central Government (Budget Performance) ....................................24

4. Operations of Nonfinancial Public Corporations..........................................................25

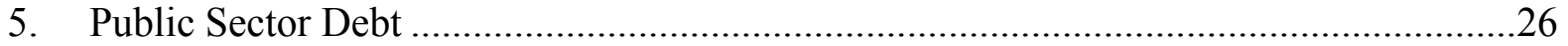

6. Selected Indicators of Tourism ..............................................................................2

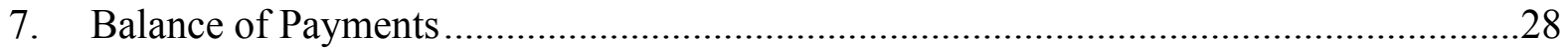

8. Summary Accounts of the Central Bank and the Financial System .............................29

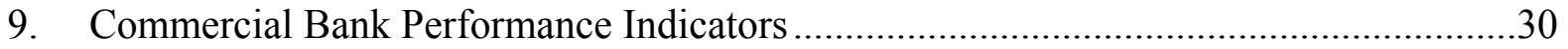

10. Indicators of External and Financial Vulnerability ................................................. 31

11. Summary Medium-Term Macro Flows: Baseline Scenario .........................................32

12. Medium-Term Balance of Payments .........................................................................33

13. Consolidated Public Sector Debt Sustainability Framework, 2002-12 ........................34

14. External Debt Sustainability Framework, 2002-12 ..................................................35

Appendices

1. Background and Summary of Appendices..............................................................36

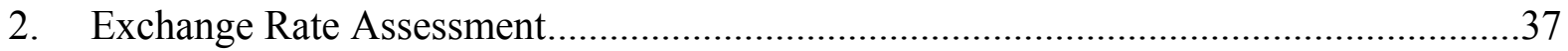




\section{BACKGROUND}

\section{The Bahamas is a small, open island economy with a relatively high income} drawn mainly from tourism and offshore financial activities. Helped by prudent macroeconomic management over the past 30 years, overall standards of living are among the highest in the Western Hemisphere. Per capita GDP is about US\$20,000, and indicators of social development and macroeconomic performance compare favorably with the rest of the Caribbean. Tourism and related activities account for roughly one-third of Bahamian GDP, and financial activities, including from its offshore center, account for over 20 percent of GDP. These sectors are expected to remain the main engines of growth in the future, and government policy is oriented towards further improving the business climate in those areas. The Bahamas maintains a more than 30-year old exchange rate parity with the U.S. dollar.

Selected Social Indicators

\begin{tabular}{|c|c|c|c|c|c|c|}
\hline & $\begin{array}{r}\text { GDP per } \\
\text { Capita } \\
\text { (Thousands of } \\
\text { U.S. dollars) }\end{array}$ & $\begin{array}{r}\text { HDI 1/ } \\
\text { (Avg. Rank, } \\
2006)\end{array}$ & $\begin{array}{r}\text { Life } \\
\text { Expectancy } \\
\text { (Years, 2006 }\end{array}$ & $\begin{array}{r}\text { Illiteracy } \\
\text { (Percent, 2006) }\end{array}$ & $\begin{array}{r}\text { Income } \\
\text { Inequality } \\
(\text { GINI index) } 2 /\end{array}$ & $\begin{array}{r}\text { Poverty } \\
\text { (Percent) }\end{array}$ \\
\hline The Bahamas & 19.2 & 52 & 71 & 6 & $\ldots$ & \\
\hline Caribbean Avg. & 7.0 & 80 & 69 & 10 & 38 & 28 \\
\hline Best & 19.2 & 31 & 77 & 0 & 10 & 12 \\
\hline Worst & 0.5 & 154 & 50 & 49 & 65 & 66 \\
\hline Developing & 5.4 & 101 & 64 & 22 & 42 & 38 \\
\hline LAC & 5.1 & 79 & 71 & 12 & 51 & 37 \\
\hline OECD 3/ & 34.6 & 20 & 78 & $\ldots$ & 33 & $\ldots$ \\
\hline
\end{tabular}

2. The Bahamas has a stable Westminster-style two-party political system. In May 2007, the Free National Movement, led by Mr. Hubert Ingraham, returned to power by a narrow electoral margin, after five years in the opposition. Continuity in economic policy is assured as both political parties endorse a private sector-led economic development model with some state involvement in infrastructure, and have demonstrated prudent financial management.

\section{RECENT DEVELOPMENTS}

3. The economic expansion that started in 2004 continued in 2006, as strong tourism-related construction and domestic demand offset a lackluster tourism sector. In 2006, real GDP grew by 3.4 percent, as construction on new resort and second-home projects increased sharply. Domestic demand was fueled by expanding bank credit to the private sector, which grew by over 14 percent a year in 2005 and 2006 (mainly in consumer loans and mortgages). These activities offset a decline in tourism arrivals (following strong growth 
in 2004 and 2005), due mainly to the recovery of competitors from hurricane damage. The unemployment rate fell by one-fourth to 7.6 percent, and estimates of the output gap suggest that the economy is operating close to capacity. Nevertheless, inflation remains subdued at around 2 percent (Figure 1).

\section{Following steady improvements in recent years, the fiscal accounts deteriorated}

\section{in FY 2006/07 mainly due to} one-off factors. Preliminary results for FY 2006/07 (ending June 30) indicate an increase in the overall deficit of the central government to 2.6 percent of GDP - 1 percent of GDP over the budget target and the FY 2005/06 outturn. The deterioration was associated with higher-than-budgeted transfers to two public enterprises and extraordinary expenditures for the renovation

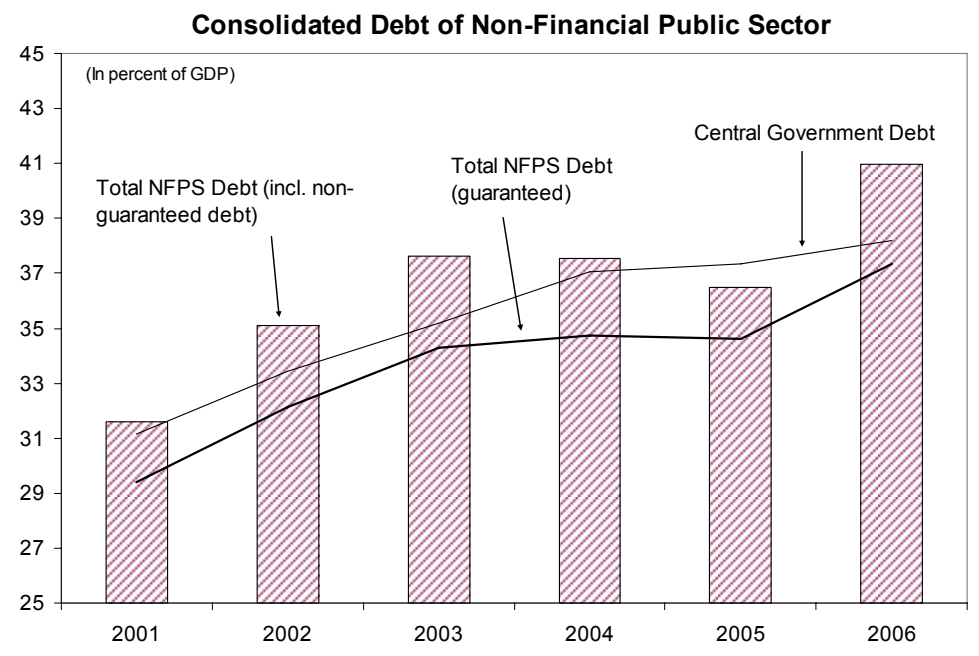
of schools. Since FY 2002/03, revenue increased by $4 \frac{1}{2}$ percentage points of GDP, to $21 \frac{1}{2}$ percent of GDP, mainly owing to buoyant import growth (in particular related to fuel imports) and improved tax collection. This has offset growth in primary recurrent spending, in particular on wages and current transfers and subsidies. Capital outlays, including transfers to public enterprises, have risen recently in the face of shortcomings in public infrastructure, but overall they remain relatively low at 3.4 percent of GDP. Public debt increased to 41 percent of GDP at end2006, mainly as a result of US\$160 million market financing by the telecommunications and electricity companies for new investment (Figure 2).

\section{Reflecting strong credit growth, net international reserves have declined to} below the authorities' informal benchmark. The lifting of a credit freeze in mid-2004 set off a vigorous expansion of credit. Credit growth has slowed this year (to 10 percent y-o-y by September) as the overhang in credit demand diminished and responded also to moral suasion by the authorities. Nevertheless, NIR have declined to around 80 percent of base money, below the central bank's informal benchmark of about 100 percent (Figure 3 ).

\section{Imports related to investment projects have led to a sharp increase in the} external current account deficit. The current account deficit can be decomposed into an underlying position plus a transitory import component related to periodic waves of foreign 
Figure 1. The Bahamas: Economic Growth

Economic activity is closely tied to that of the United States.

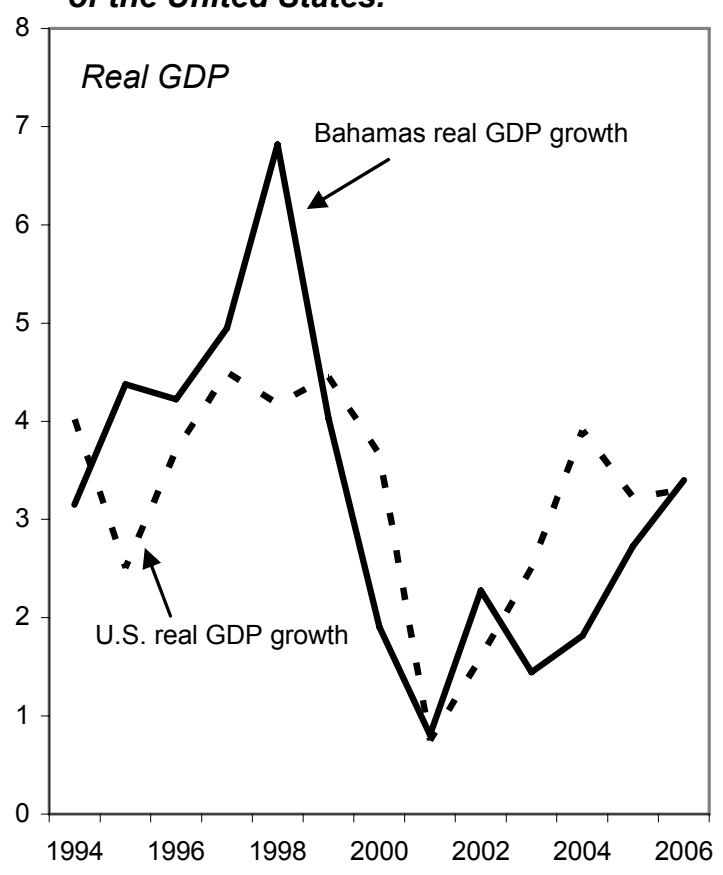

...strong credit growth...

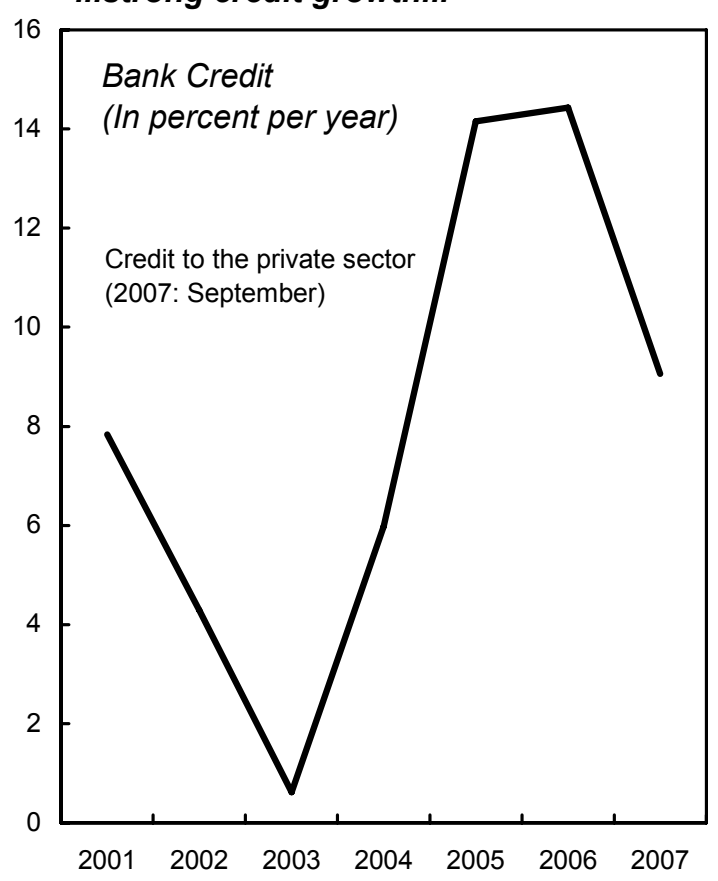

Growth has also been determined by FDI-financed hotel construction...
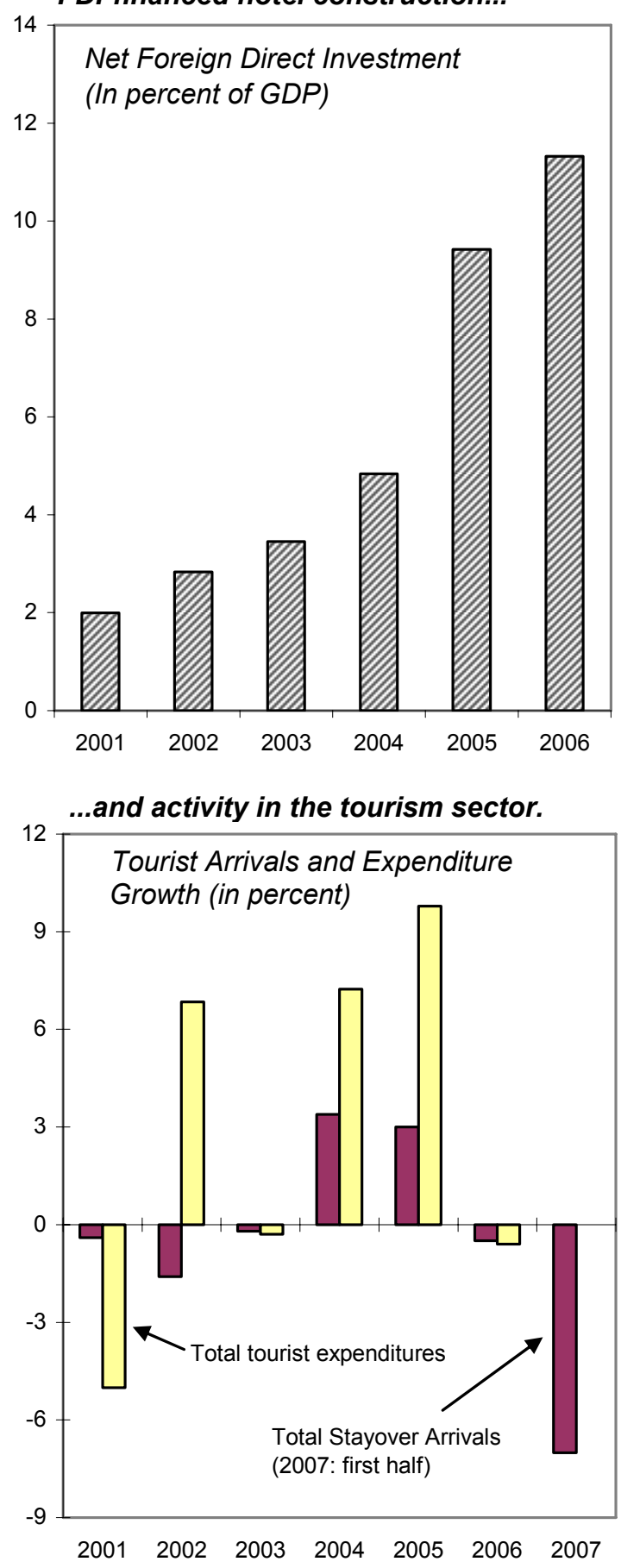

Sources: IMF, International Financial Statistics; Fund staff estimates; and the Central Bank of the Bahamas. 
Figure 2. The Bahamas: Fiscal Developments (In percent of GDP) 1/

Fiscal revenues increased markedly due to cyclical factors and improved administration...

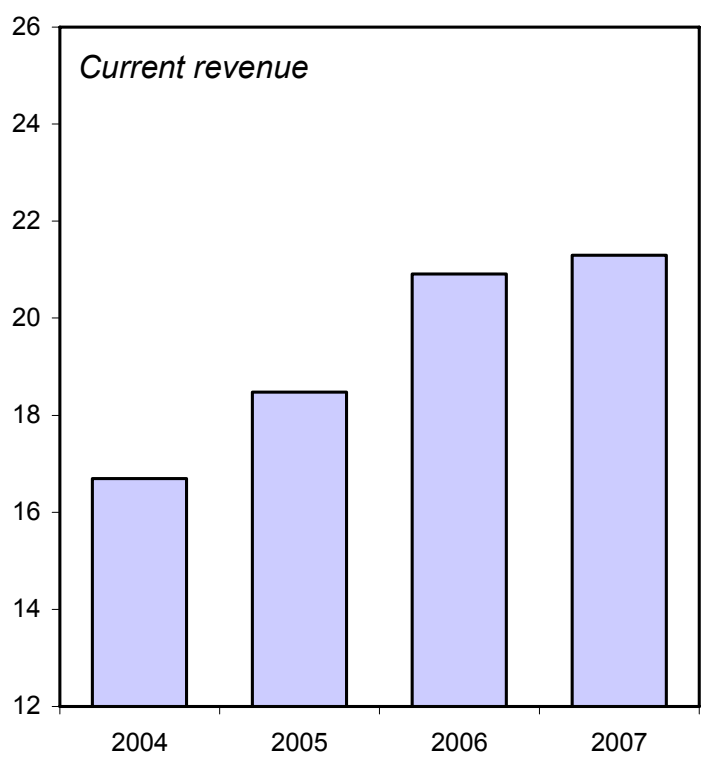

...partly reversed the trend toward fiscal consolidation.

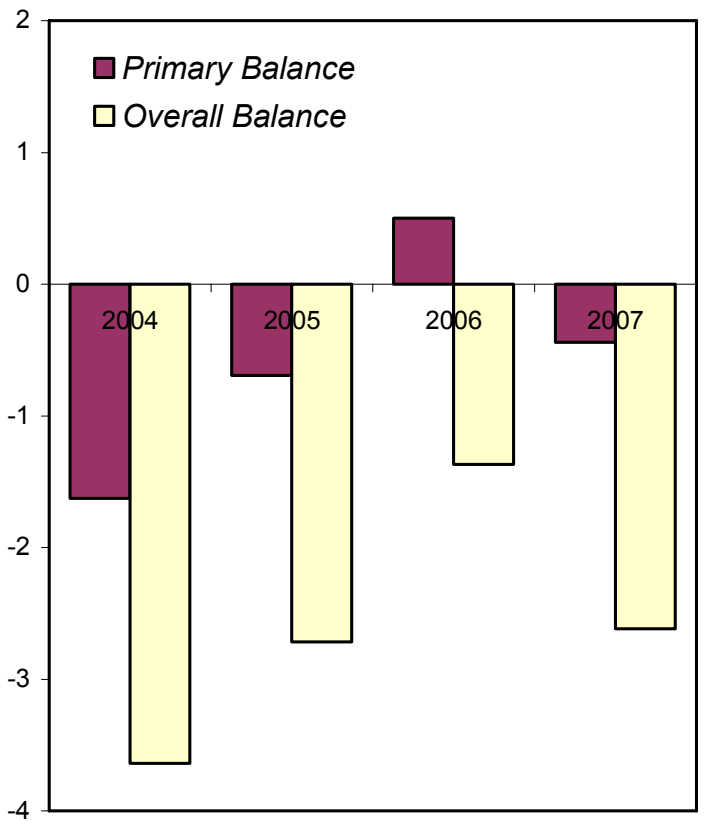

\section{...but strong expenditure growth in FY 2006/07...}

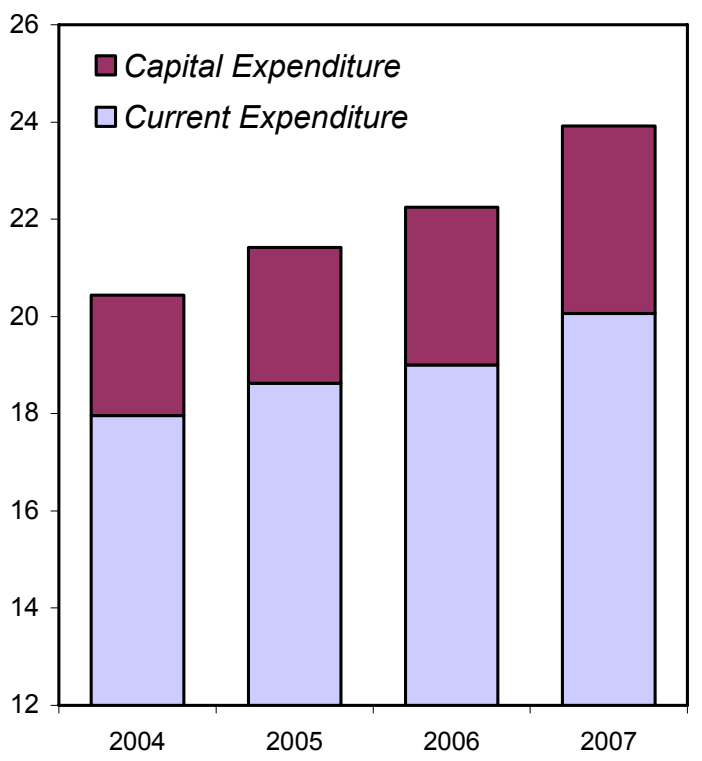

The government's debt-to-GDP ratio has risen to 38 percent of GDP.

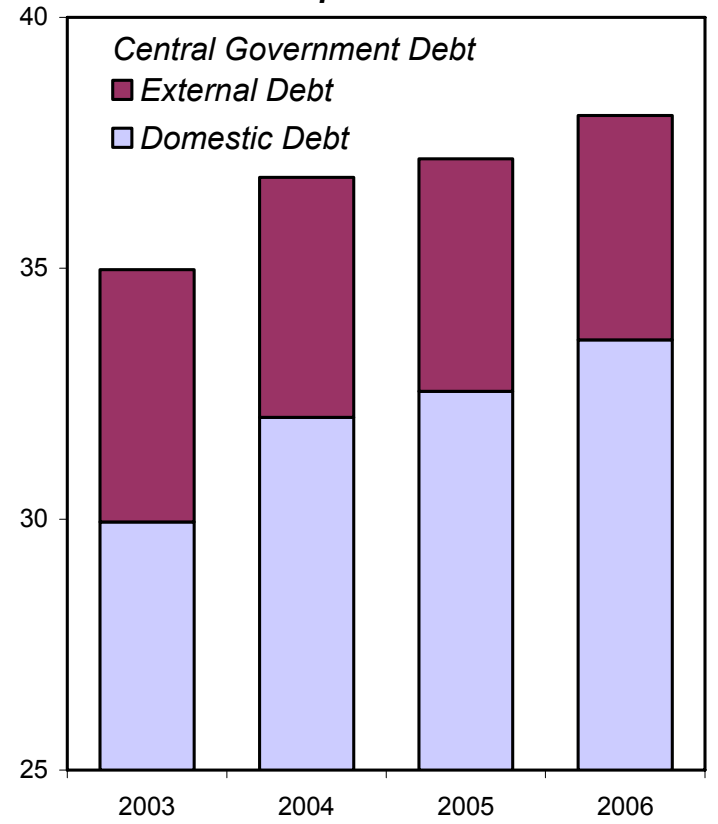

Sources: The Central Bank of the Bahamas; and Fund staff estimates and projections. $1 /$ Central government; fiscal year ending June 30. Debt data is on calendar year basis. 
Figure 3. The Bahamas: Monetary Developments
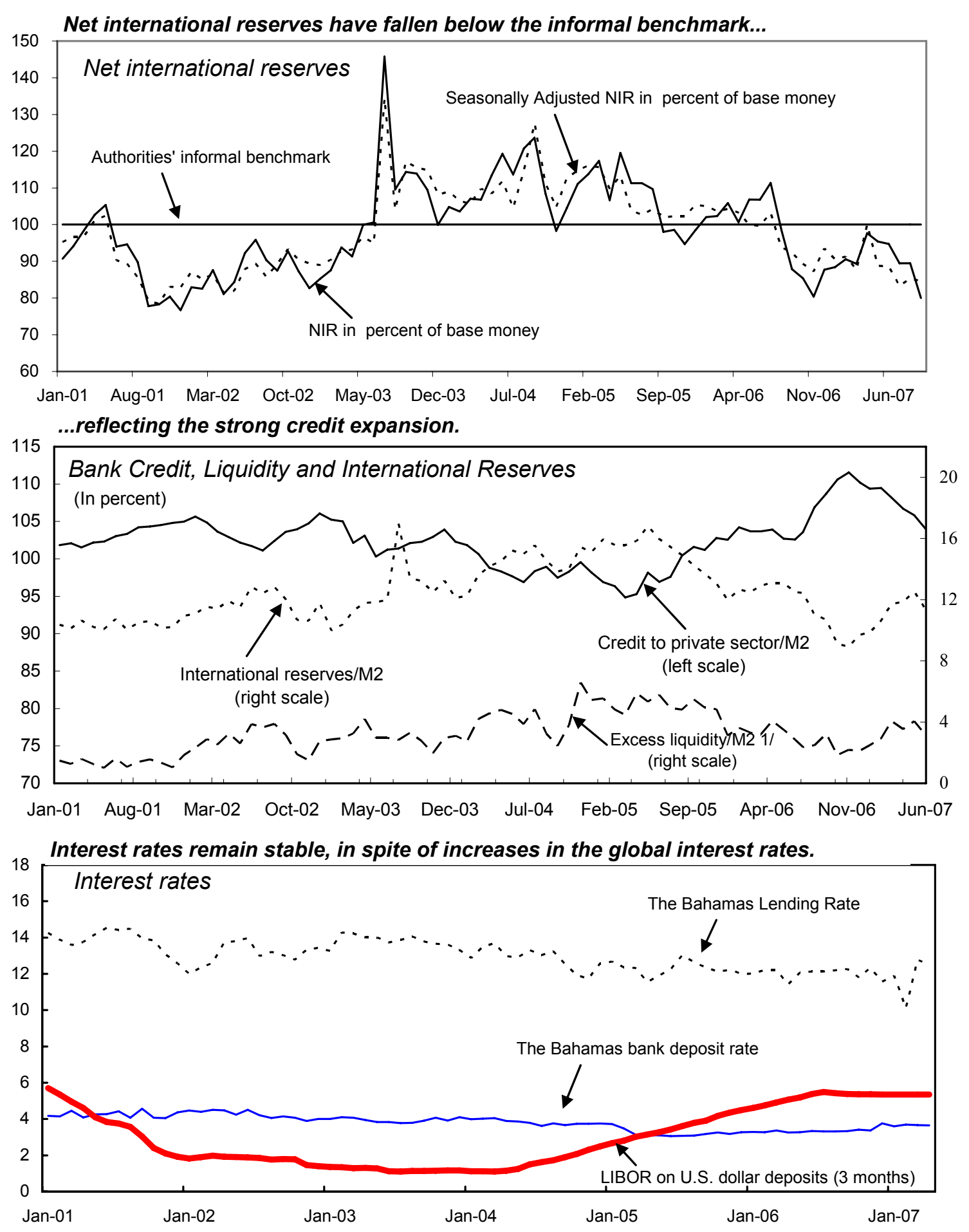

Sources: IMF, International Financial Statistics; and The Bahamas Central Bank.

1/ Cash-in-vault and deposits at the central bank minus required reserves. 
direct investment (FDI) in tourism-related construction projects. ${ }^{1}$ Thus, although the actual current account deficit increased from $8 \frac{1}{2}$ percent of GDP to $25 \frac{1}{2}$ percent between 2003 and 2006 , the underlying current account deficit rose by much less, from $81 / 2$ percent of GDP in 2003 to around $10^{1 / 2}$ percent, reflecting higher oil prices. A similar situation occurred in 1997-98, when the current account deficit rose from 7.5 percent of GDP in 1996 to 23.2 percent of GDP in 1998 following a hotel construction boom. Over the next two years, the deficit fell back to 8 percent of GDP, while tourist expenditure rose by 3 percent of GDP.

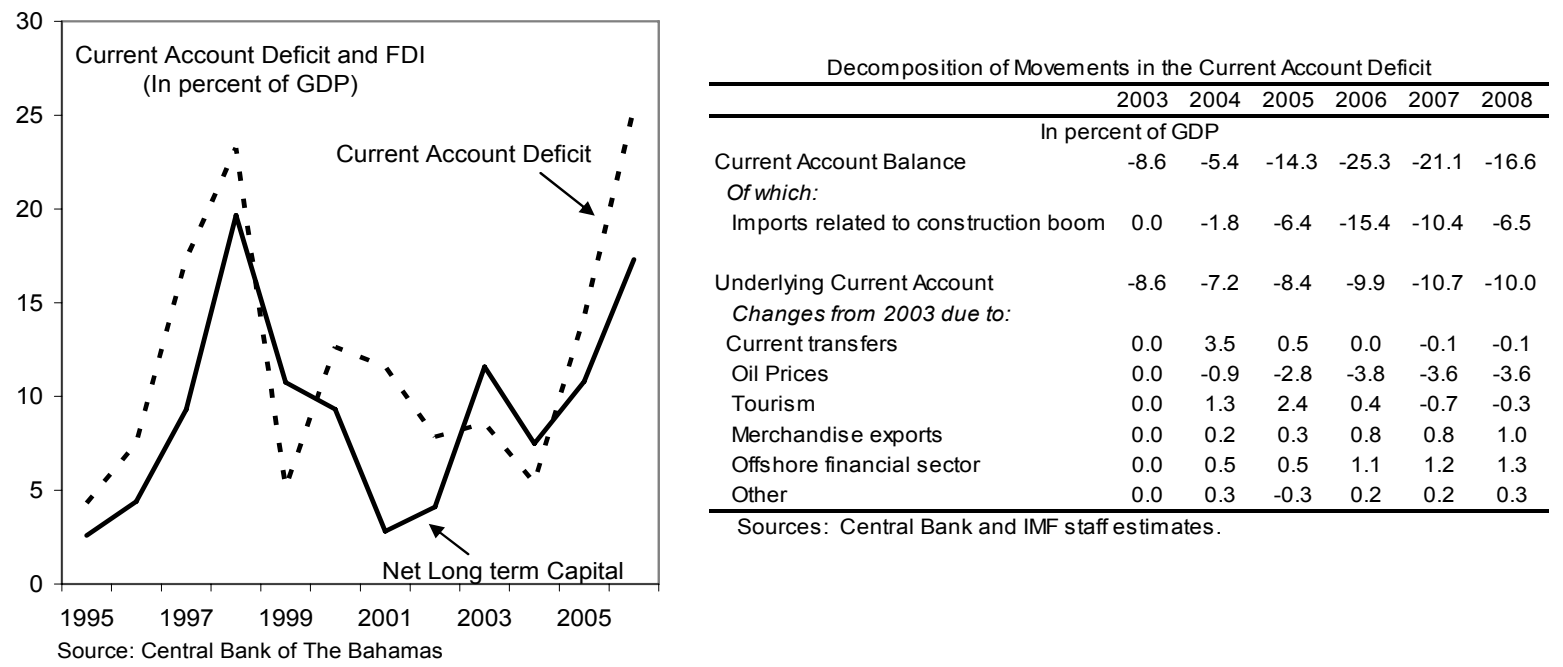

7. Notwithstanding the recent lackluster tourism activity, standard indicators do not suggest a decline in competitiveness or threat to external stability. According to various measures, the real effective exchange rate has depreciated significantly in recent years. ${ }^{2}$ Merchandise exports (net of re-exports) have grown steadily, from $6 \frac{1}{4}$ percent of GDP in 2003 to close to 7 percent in 2006, while receipts from the offshore financial sector have risen from 1.9 percent of GDP to 3 percent. In tourism, despite a loss in market share of Caribbean stop-over arrivals, The Bahamas' share of total Caribbean tourism expenditure has increased, in part reflecting a deliberate strategy to target the higher end of the market. In addition, buoyant FDI points to a high level of investor confidence and prospects of future improvements in productivity, and The Bahamas ranks high in terms of investment climate indicators, including the level of taxation, rule of law, and corruption (Figure 4).

\footnotetext{
1 The underlying current account balance is calculated assuming that imports of construction services, other services (which are mainly related to construction) and merchandise (including fuel quantity) remain constant as a share of GDP.

${ }^{2}$ In addition, an estimate of the equilibrium real exchange rate suggests that the actual rate is not overvalued (Appendix II).
} 
Figure 4. The Bahamas: Competitiveness Indicators
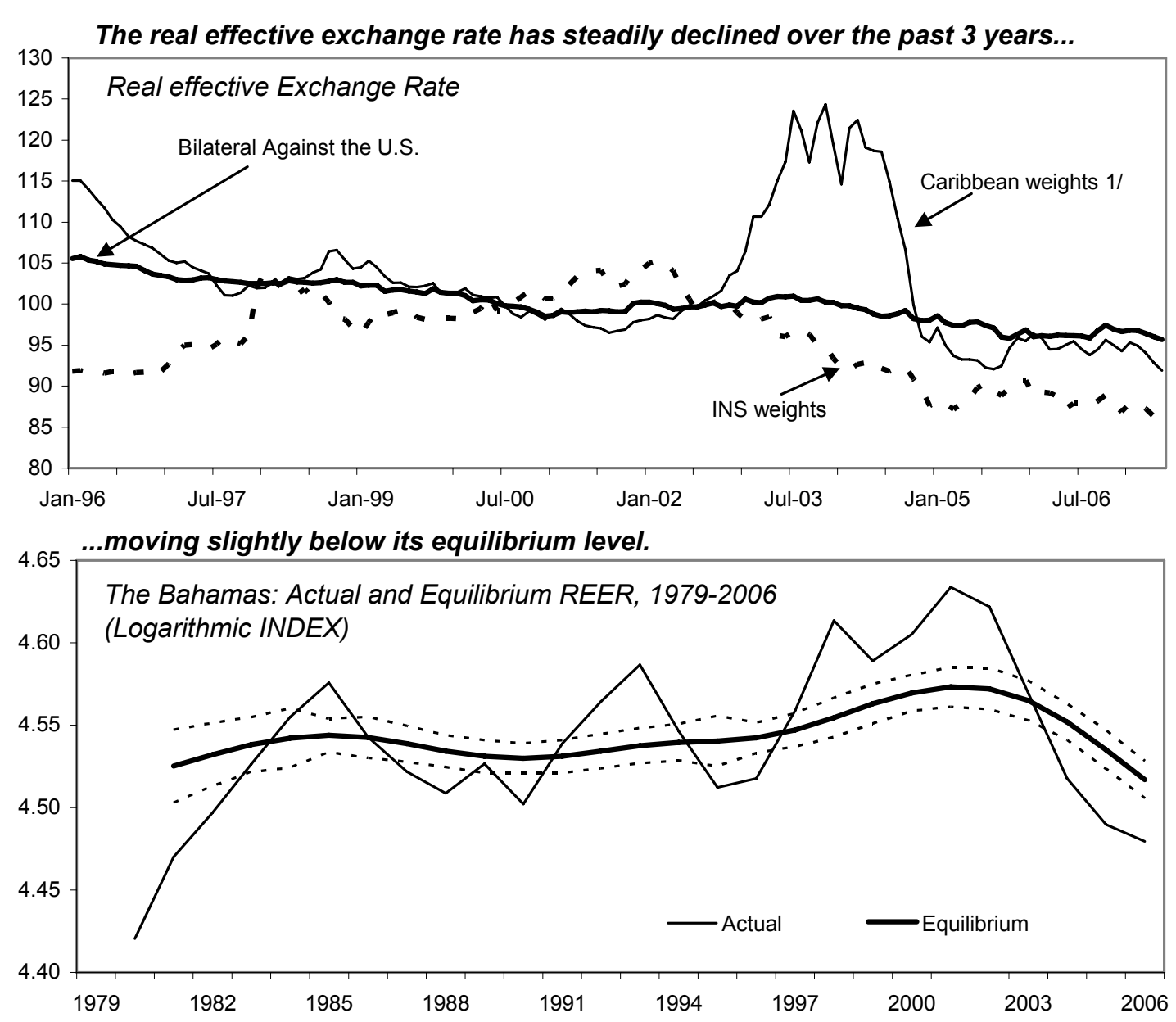

Although losing market share in terms of tourist arrivals, The Bahamas has gained

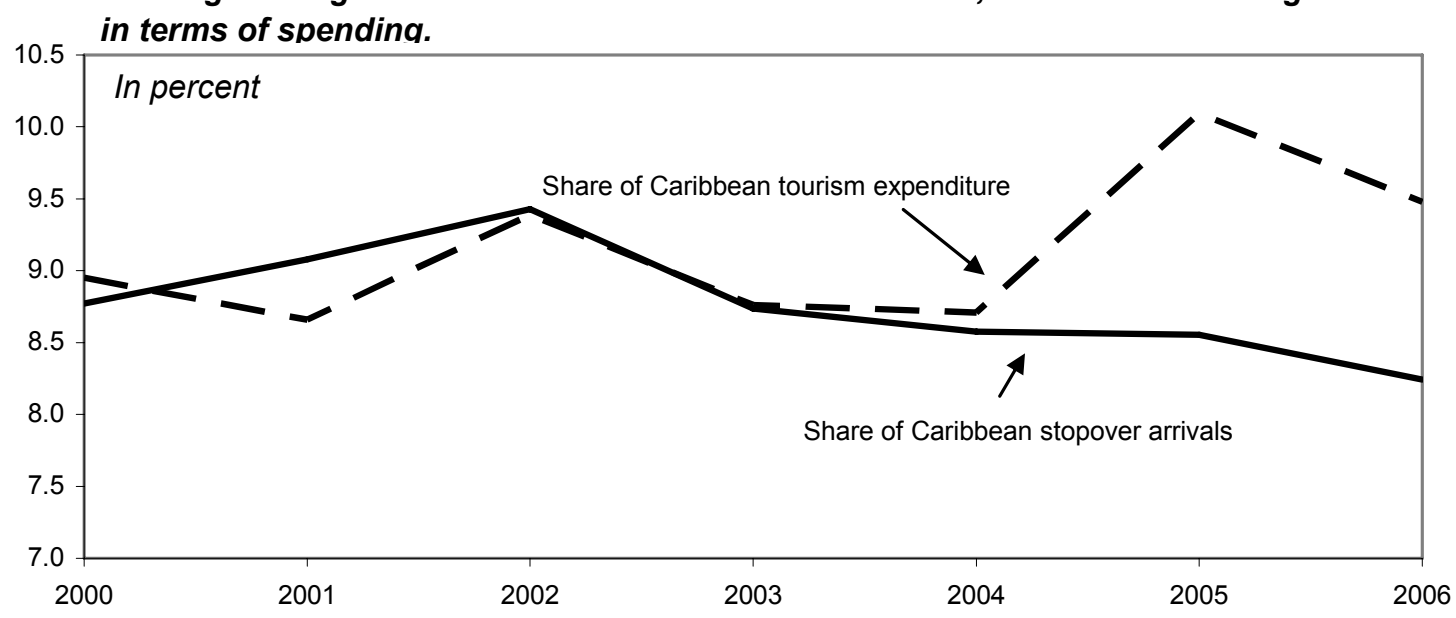

Sources: IMF, International Financial Statistics; The Bahamas Ministry of Tourism; and Fund staff estimates. 
Governance Matters Index: Worldwide Governance Indicators, 2006

(Selected countries) 1/

\begin{tabular}{|c|c|c|c|c|c|c|}
\hline & Bahamas & Barbados & Jamaica & Panama & $\begin{array}{c}\text { United } \\
\text { Kingdom }\end{array}$ & $\begin{array}{l}\text { United } \\
\text { States }\end{array}$ \\
\hline Voice \& accountability & 0.87 & 0.84 & 0.68 & 0.66 & 0.83 & 0.76 \\
\hline Political stability & 0.84 & 0.79 & 0.56 & 0.67 & 0.71 & 0.68 \\
\hline Government effectivenes & 0.62 & 0.52 & 0.51 & 0.50 & 0.70 & 0.69 \\
\hline Regulatory quality & 0.83 & 0.64 & 0.61 & 0.66 & 0.84 & 0.78 \\
\hline Rule of law & 0.86 & 0.75 & 0.48 & 0.54 & 0.86 & 0.81 \\
\hline Control of corruption & 0.78 & 0.67 & 0.33 & 0.44 & 0.80 & 0.71 \\
\hline Average & 0.80 & 0.70 & 0.53 & 0.58 & 0.79 & 0.74 \\
\hline
\end{tabular}

Source: World Bank Institute, based on averaged ratings of international ratings (www.govindicators.org; www.worldbank.org/wbi/governance/).

$1 /$ Index is average of ratings by a number of international multilateral and non-governm organizations, normalized to the $0-1$ range, with 1 being the best.

\section{Financial soundness indicators point to a healthy and well-supervised system.}

The Bahamian banking sector has experienced healthy growth rates since 2003, with total assets growing from 109 percent to 125 percent of GDP in 2006. At the same time, profitability and capital adequacy have improved, while the ratio of nonperforming loans to total loans has steadily declined. Substantial efforts have been made to bring banking supervision up to international standards, harmonize domestic and offshore regulations, and comply with the Basel core principles for bank supervision. New bank and private trust company regulations have been implemented, including to specify limits of bank lending exposure, improve know-your-customer provisions, impose meaningful physical presence requirements for all banks and trusts, and consolidate anti-money laundering legislation in line with international best practices. Partly because of exchange control regulations, which severely restrict domestic banks from investing abroad and create a firewall between the domestic and offshore financial sectors, the domestic financial system has not been affected by the recent turmoil in global financial markets. 


\section{OUTLOOK FOR 2007-08 AND THE MEDIUM TERM}

\section{Economic growth in $\mathbf{2 0 0 7}$ is expected to decelerate moderately and then to} rebound in 2008. This year growth is projected to fall to around 3 percent, owing mainly to the deceleration in the expansion of credit, the completion of a major hotel construction project, and continued weakness in tourism arrivals. Tourism has been affected by the Western Hemisphere Travel Initiative (the requirement that U.S. tourists must have a passport to re-enter their country), a slowdown in U.S. economic activity, and the withdrawal of a significant number of hotel rooms for renovation and remodeling. In 2008, growth is projected to rise to around 4 percent, based mainly on a rebound in tourist activity as new and upgraded facilities come on stream, even as global economic conditions become somewhat less favorable. The FY 2007/08 fiscal deficit is projected at 1.8 percent of GDP, consistent with the official budget estimate, and the current account deficit is projected to fall to $16 \frac{1}{2}$ percent of GDP in 2008 , reflecting further moderation in hotel construction.

Macroeconomic Framework

(In percent of GDP, unless otherwise indicated)

\begin{tabular}{lrrrrrr}
\hline & & & & & \multicolumn{2}{c}{ Proj. } \\
\cline { 5 - 7 } & 2003 & 2004 & 2005 & 2006 & 2007 & 2008 \\
\hline Real GDP growth (in percent) & 1.4 & 1.8 & 2.5 & 3.4 & 3.1 & 4.0 \\
Stayover arrivals (percentage change) & -0.2 & 3.4 & 3.0 & -0.5 & -1.4 & 4.0 \\
Inflation (in percent; end of period) & 3.0 & 0.9 & 2.2 & 1.8 & 2.4 & 2.4 \\
External current account & -8.6 & -5.4 & -14.3 & -25.3 & -21.1 & -16.6 \\
Net international reserves & & & & & & \\
$\quad$ In percent of base money & 99.9 & 104.5 & 98.5 & 87.7 & 83.6 & 89.8 \\
$\quad$ In months of goods imports & 3.3 & 4.2 & 2.9 & 2.3 & 2.3 & 2.5 \\
Central government & & & & & & \\
$\quad$ Primary balance 1/ & -1.6 & -1.2 & -0.9 & 0.2 & -0.5 & 0.4 \\
$\quad$ Overall balance 1/ & -3.4 & -3.2 & -2.9 & -1.7 & -2.6 & -1.8 \\
$\quad$ Debt (end of period) & 49.9 & 50.2 & 49.2 & 53.2 & 54.8 & $\ldots$ \\
\hline
\end{tabular}

$1 /$ Fiscal year ending June 30.

10. The main downside risk is that of a sharper slowdown in the United States. The mission's baseline forecast already incorporates some spillover effects to The Bahamas from a slowdown of the U.S. economy in line with the WEO projections: (a) tighter credit conditions in the United States, especially for real estate companies and potential secondhome buyers; and (b) subdued U.S. economic activity and consumer confidence, which would impact tourism. In the event of a sharper U.S. slowdown, the negative impact on the Bahamian economy might be stronger than projected, not only from direct effects on tourist expenditures and capital inflows, but also because the authorities might need to tighten monetary policy to prevent a loss of reserves. The Bahamas is also vulnerable to hurricanes. 


\section{Medium-term prospects for growth and external stability depend on healthy}

tourism growth. The underlying current account deficit is projected to decline to around $81 / 2$ percent of GDP by 2012 as the rise in oil imports is offset by a recovery in tourism and continued growth of exports and the financial sector. Tourism receipts are assumed to increase from $32 \frac{1}{2}$ percent of GDP in 2006 to $33 \frac{1}{2}$ percent in the medium term (the $1997-$ 2006 average), consistent with projected economic growth in the United States and Canada, and the maintenance of The Bahamas' competitive position as a result of the upgrading and expansion of the hotel stock now underway.

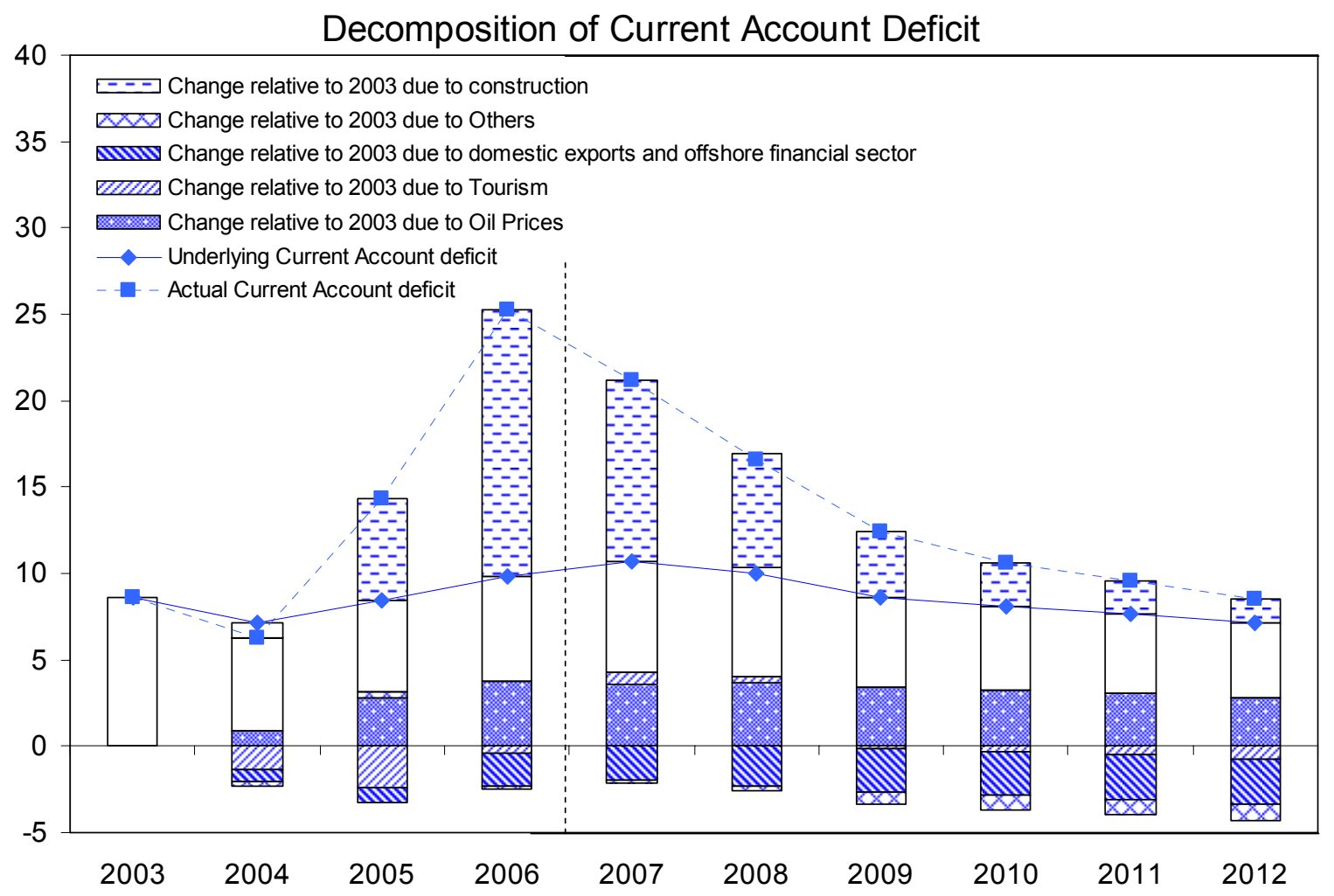

12. Though currently in large deficit, the current account position appears sustainable, based on projected long-term equity-related capital flows in line with the average of the last 10 years. In the past, these flows have been largely immune to the periodic bouts of volatility in international capital markets and have been underpinned by The Bahamas' strong fundamentals, including its stable macroeconomic conditions and a favorable investment climate. Nevertheless, the need for inflows of this magnitude does expose The Bahamas to potential capital account vulnerabilities. External debt is negligible (5.9 percent of GDP) and does not pose a threat to external stability under standardized shocks. Public external debt is around 5 percent of GDP, and partly owing to exchange controls, private external debt is also very low (0.6 percent of GDP). 


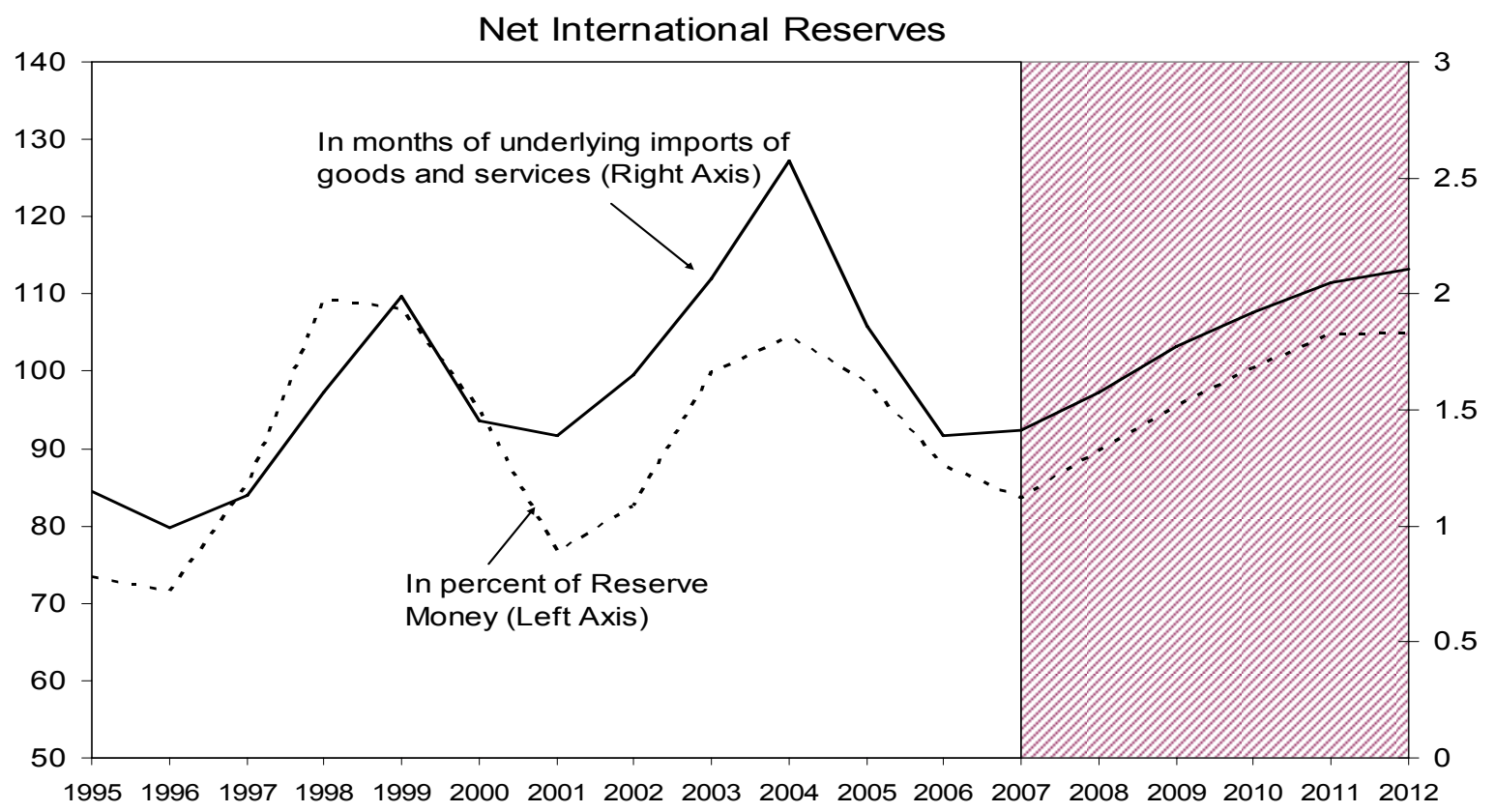

13. There is also a sizable upside risk to the long-term growth outlook. Some US\$1320 billion (200-330 percent of GDP) of hotel and second-home projects have been proposed for consideration by the government. The projects are at various stages of negotiation and approval, and only a small number of them are included in the projections. Thus, hotel and home construction could be substantially stronger than projected, raising the risk of overheating.

\section{Policy Discussions}

\section{The authorities' main economic objectives are to maintain macroeconomic} stability and a positive investment climate. They see this as the best way to encourage private investment and ensure continued growth in employment and standards of living. Against this background, discussions focused on the economic outlook, policies to maintain macroeconomic stability, and structural reforms to enhance overall efficiency.

\section{Economic outlook}

\section{Medium-term prospects are favorable but the highly competitive regional} tourism market and high oil prices pose challenges. If lackluster tourism growth were to continue and thus also discourage future FDI, this would not only impact the current account deficit but capital account financing could also decline. The staff encouraged the authorities to continue to explore ways to broaden the tourist base, which, more than for any other Caribbean country, is narrowly concentrated on the U.S. market. Developing new tourism products in line with preferences of European and emerging market tourists could help achieve this objective. In addition, this could create opportunities for niche developments and 
Bahamian entrepreneurs, which the government would like to promote. Hotel operators also cited a need to improve education and vocational training to address a skills shortage in the tourism sector.

\section{The authorities and private sector representatives were optimistic about the}

sector's future. They noted recent initiatives to expand the tourist base to Europe and Asia; new agreements to increase airline flights between the United States and The Bahamas; and the world-class hotel companies undertaking new investments in the country. They also cited the potential for expansion into the largely undeveloped outer islands, and the demographic shift of the North American population - the "graying" of the relatively affluent baby boom generation that has boosted demand for high-end tourist travel and second-home purchases, which is assumed to be less sensitive to cyclical or credit market conditions.

\section{The authorities shared the staff's concerns about the country's ability to absorb} the large amount of hotel projects being proposed by developers. The authorities have established an inter-ministerial task force to carefully monitor potential bottlenecks in public infrastructure and services that might arise from the hotel construction. At the same time, they are carefully reviewing the hotel project proposals to ensure consistency with environmental sustainability, labor force capacity, and the local culture. This is especially relevant in the isolated and sparsely populated outer islands, where the authorities have decided to abandon the previous government's strategy of encouraging the establishment of large-scale resorts ("anchor projects") to serve as engines of growth and development.

\section{Exchange rate policy}

18. The staff and authorities agreed that the fixed exchange rate regime and parity with the U.S. dollar are appropriate. The small size of the economy and its strong economic and commercial ties with the United States argue for maintaining the peg. It has fostered a favorable investment climate by eliminating exchange rate risk and allowing for long-term investment planning. Moreover, there is no evidence that maintaining parity with the U.S. dollar has hurt competitiveness or negatively affected external stability. The authorities reiterated their commitment to economic policies consistent with supporting the exchange rate parity.

\section{Fiscal policy}

\section{The authorities' fiscal policy is anchored on the medium-term objectives of} balancing the budget and reducing debt. The authorities reiterated their commitmentoutlined in the FY 2007/08 budget speech - to balance the budget and reduce central government debt to 30-35 percent of GDP by the end of their term in 2012. The staff endorsed these goals, noting that their achievement would further increase the room to maneuver in the event of shocks, and support the central bank's efforts to accumulate international reserves and the planned further relaxation of exchange controls. The staff 
added that, if economic activity turned out stronger than projected, it would be advisable to accelerate the pace of fiscal consolidation, to reduce the risk of overheating.

20. Controlling recurrent primary spending will be a priority. Such spending has grown at a fast and unsustainable pace in the past three years. Restraint in this area would create room for much needed infrastructure spending. The authorities noted that they had taken measures to further enhance the credibility of the budgetary and fiscal planning process. To limit supplementary appropriations and enhance transparency, they have committed to hold a formal midyear review of budget implementation in Parliament and grant only thoroughly justified additional expenditure. In addition, the medium-term fiscal deficit and debt-reduction objectives will be assessed within the framework of rolling 3-year projections.

\section{The authorities intend to strengthen the budget constraints on public entities.}

Extraordinary transfers to state agencies ( $1 / 2$ percent of GDP) contributed to the FY 2006/07 budget overrun. Two ailing public enterprises will be the focus of tighter budget control in the context of renewed management performance and investment plans. The authorities confirmed their intention to proceed with the privatization of the profitable state telecommunications and electricity companies.

\section{On revenues, the authorities are focusing on improving the efficiency of tax} administration. Efforts to improve administration include computerization, more focused controls at customs, a better follow-up on tax arrears, and some streamlining of import and stamp duties. In addition, they are working to improve collection of real estate taxes and update the tax base. The authorities have no near-term plans for major tax policy changes, although they noted that they may eventually need to adopt a consumption tax or VAT to reduce dependence on import tariffs, depending on negotiations of regional and international trade agreements. The Bahamas has the highest average customs tariff rate among Fund members and the authorities are aware of the potential efficiency gains from adopting a VAT. However, with a high import content of consumption, the authorities see the advantages of a VAT over import tariffs as relatively small and they are not convinced that these would outweigh the costs and disruptions at this time from such a far-reaching move.

23. Import duty exemptions and tax concessions are generous. Concessions granted to encourage hotel investment include import duty exemptions on investment-related goods as well as long-term exemptions from real estate taxes. Import duty exemptions accounted for B \$80 million (1.3 percent of GDP) in FY 2005/06. The large amount of hotel projects being proposed by the private sector suggests that the existing level of concessions may be overly generous. Moreover, the staff noted that concessions implicitly favor imports over domestically provided goods and services. The authorities agreed, and are reviewing the statutory import duty exemptions and tax concessions granted under the Hotel Investment Act and other legislation. For the time being, in their negotiations with promoters, they will try to limit the scope of the entitlements to pure hotel projects, excluding the second-home 
and other real estate type developments that are not specifically covered under the concessions law. The authorities are also reviewing previously signed agreements to ensure that concessions offered to developers were in full compliance with other areas of Bahamian law. Despite these initiatives, however, the authorities were of the view that the regional competition for hotel investment would not permit a substantial reduction in the use of tax concessions to attract investment.

\section{Monetary policy}

24. Monetary policy remains geared toward supporting the exchange rate peg. The authorities noted that credit growth had come down, and that the external position was solid, even though they agreed with the staff's assessment that the level of international reserves could be higher. The authorities emphasized that they were monitoring the situation closely and would not hesitate to use all the tools at their disposal, including credit restrictions, in order to safeguard the reserve position and the peg. They also noted that they had contingent lines of credit with the commercial banks, in the event that there was a short-term need to augment reserves.

\section{Staff considered that some additional tightening of monetary conditions was}

warranted. While the current level of international reserves was not an immediate cause for concern, current economic trends warranted additional caution, and the staff argued that the authorities should try to accumulate reserves now by moderating the growth of credit. The present level was significantly below the central bank's own benchmark of 100 percent of base money, in the context of the exchange rate peg. A higher level of reserves would provide a buffer against the present downside risks in the global economy, such as the credit crunch, a weaker current account from smaller-than-projected tourism expansion, or a further increase in oil prices. Over the medium term, a higher level of reserves would also be appropriate to accompany the planned further easing of exchange controls (paragraph 27).

\section{The staff endorsed the authorities' plan to move toward market-oriented}

instruments of monetary policy. The authorities currently rely mainly on moral suasion, credit ceilings, and transfer restrictions as their policy instruments. Greater reliance on market-oriented monetary instruments will allow the authorities to "fine tune" their liquidity management operations and could help improve economic efficiency and competitiveness, by contributing to the development of domestic capital markets and improving the efficiency of the allocation of credit. The authorities have already begun to explore options for "openmarket-type" operations to help manage overall bank liquidity (such as purchases of some of the central bank's stock of government securities by the National Insurance Board, which has substantial bank deposits). The authorities were pleased with the MCM/CARTAC technical assistance mission on the use of indirect monetary policy instruments that took place in October and looked forward to receiving the mission's final report (Box 1). 


\section{Box 1. The Introduction of Indirect Instruments of Monetary Policy}

The central bank is exploring a possible move from direct controls to the use of indirect instruments of monetary policy. The move would involve a change to the monetary operations framework and a more explicit use of interest rate levers to influence credit demand. The use of indirect levers should allow for more effective and efficient implementation of monetary policy, and support financial market deepening. It should also provide a framework which is more robust in responding to financial market development and the pressures of globalization.

Currently, the authorities' main monetary policy instruments are moral suasion and credit restrictions, although they do possess some indirect instruments. In 2006, in order to moderate the growth of credit, the authorities successfully resorted to moral suasion in the form of various letters and consultations with commercial banks. A standing facility for providing liquidity exists notionally in the form of a discount window. The discount rate does have market impact, as it effectively determines the banking sector's prime rate, and most loans - including government bonds - are priced on the basis of the prime rate.

However, in practice, the discount rate has not been used actively (the rate has changed only twice in the last ten years) and thus has not reflected changes in the monetary policy stance.

A number of changes to the central bank's operational framework will be needed to support the adoption of indirect instruments. These include: improving balance of payments forecasts and elaborating a short-term liquidity forecast; adjusting the reserve averaging system; and replacing the existing discount and rediscount facilities with a more normal standing credit facility where the central bank has more control over the terms and conditions of borrowing. It would also be important for the government's overdraft ("advances") from the central bank to be securitized or repaid, and for the central bank to gradually sell some of its holdings of government securities to the market to remove existing excess liquidity.

With these measures in place, the authorities would be in a position to implement open market operations to manage liquidity and guide the short-term market interest rate. The central bank's monetary policy committee would periodically set a monetary policy rate, which would then replace the discount rate as a base for other market rates.

\section{Financial sector policies}

27. The planned further easing of exchange controls is welcome and needs to be well supported by strong macroeconomic and financial sector policies. Inward and outward capital transactions by residents currently require authorization by the central bank, and approved amounts are limited and carry high fees. Further relaxation of controls would foster development of capital markets and enhance investment opportunities for Bahamians and 
foreigners, while also facilitating Bahamas to keep up with spontaneous developments of globalization and regional integration of the financial system. On the other hand, it would also reduce monetary policy independence and potentially increase the vulnerability of the fixed exchange rate regime. The staff supported the authorities' gradual and controlled approach, emphasizing that it should be accompanied by a higher benchmark level of international reserves, indirect instruments of monetary control, solid fiscal policy, and a strong financial regulatory and prudential framework.

28. The authorities continue to place high priority on enhancing the supervisory and regulatory framework for the domestic and offshore financial systems. They have devoted substantial resources to upgrading personnel and practices in the supervision department of the central bank, which has grown into the largest department in the bank. This has allowed them to undertake on site inspections for all the banks at least once every two years. At the same time, they have strengthened risk-based supervision, including the development of watch lists for complex and potentially risky products, which has allowed them to focus their efforts more efficiently. The authorities also noted the progress made in the area of anti-money laundering and combating the financing of terrorism (AML/CFT). They continue to provide extensive training and guidelines to commercial banks, which has enabled them to move successfully from a prescriptive to a more efficient risk-based system.

\section{The authorities have taken steps to implement most of the recommendations of} the Fund's 2004 offshore financial center assessment report. An important pending measure is finalizing the guidelines on confidentiality for overseas regulators, in order to permit the efficient exchange of information.

\section{Trade and regional integration}

30. Trade integration and regional cooperation remain important objectives, within the country's priorities. The government has requested WTO membership; discussions are at a very preliminary stage. The authorities are also hopeful that the U.S. Congress will extend - and enhance - the Caribbean Basin Initiative, which is due to expire on September 30,2008. Given that merchandise exports are a relatively small component of The Bahamas' total trade, the degree of preferential access to export markets is important to only a few sectors or firms. However, to the extent that such access is important to those sectors, it remains a priority for the government. The authorities would naturally attach greater strategic importance and a higher priority to international talks that might affect tourism or financial services, given their much larger weight in the structure of the Bahamian economy. The authorities noted that they remain committed to CARICOM and have an interest in strong regional cooperation in specific areas, such as health, education, and security, but would not participate in the Caribbean Single Market Economy, as there was little political support in The Bahamas for liberalized regional immigration and currency union. 


\section{Statistical issues}

31. Progress has been made in strengthening the statistical base. A new and upgraded series of national accounts has been published, and time lags for this year's second edition were shortened substantially. A number of comprehensive surveys are in preparation, including an economic census of all enterprises, covering for the first time also the outer islands. On the other hand, resource limitations in the Department of Statistics are hampering the timely production of comprehensive economic statistics, and improved data in the area of the national accounts, external trade, the consolidated public sector, debt, and the labor market would facilitate economic monitoring and policy making.

\section{Staff Appraisal}

\section{Paced by a hotel and second-home construction boom, macroeconomic} performance over the past two years has been favorable. Real GDP has grown at a solid pace, contributing to a sharp reduction in the unemployment rate. Tourism arrivals have declined recently, mainly as a result of the recovery of competitors from hurricane damage and new U.S. travel regulations, but a rebound is expected for next year. A sharp increase in the current account deficit reflected imports related to hotel projects financed mainly by foreign direct investment. Inflation remains low and under control. The fiscal accounts deteriorated in FY 2006/07 mainly due to one-off factors, but both the deficit and public debt are relatively low and are not a significant source of vulnerability for the economy.

33. The near-term outlook remains positive, but risks have increased. Growth is projected to rebound next year based on the expectation that a new round of hotel construction will get underway and tourist activity will recover as new and upgraded facilities come on stream. However, this recovery may be tempered if U.S. economic activity turns out to be weaker than currently projected. The fiscal deficit is projected to resume its declining path in FY 2007/08.

\section{Medium-term prospects are also favorable and consistent with continuing} external stability, although the external environment may pose challenges. The Bahamas will have to contend with a highly competitive regional tourism market and the likelihood of continued high oil prices. It is also vulnerable to natural disasters. Nevertheless, based on strong investment in tourism capacity, and the supportive macroeconomic policy framework in place, the external current account deficit is expected to decline steadily. In addition, the outlook for foreign direct investment remains favorable, underpinned by strong business climate indicators, including on macroeconomic stability, low taxation, rule of law, and corruption.

35. The fixed exchange rate regime and parity with the U.S. dollar are appropriate given the small size of the economy and its economic integration with the United States. The peg has contributed to a favorable investment climate and, notwithstanding the recent 
stagnation in tourism activity, various indicators do not suggest a decline in competitiveness. Although the fixed exchange rate limits policy flexibility in the event of adverse shocks, there is a strong social consensus in favor of the peg and the policy framework needed to support it.

36. The government's goals of balancing the budget and reducing debt to 3035 percent of GDP by 2012 are well placed. Achieving these objectives would reinforce both internal and external stability while increasing the resiliency of the economy in the event of shocks. The authorities should stand ready to accelerate the pace of fiscal consolidation in the event that stronger than anticipated growth and foreign investment were to increase the risk of overheating.

37. To achieve the targets, it will be important to restrain the growth of recurrent primary spending which has expanded at a rapid pace in recent years. The government's use of a multi-year budgetary framework and its intention to introduce a formal midyear budget review are commendable, promoting transparency and greater accountability in fiscal management.

38. On revenues, plans to improve tax administration, streamline import duties, and tighten requirements for granting tax concessions are in the right direction. The large amount of hotel projects being proposed by the private sector is an indication that tax concessions may be overly generous. Depending on the authorities' plans to participate in regional and international trade agreements, the authorities would need to reduce dependence on international trade taxes and adopt a consumption tax or VAT.

39. The central bank should accumulate additional reserves by moderating credit growth. An increase in international reserves closer to historical levels in relation to monetary aggregates would provide more policy flexibility in the event of adverse shocks. Furthermore, the planned relaxation of exchange controls calls for maintaining higher levels of reserves than in the past.

40. Steps towards the eventual adoption of market-oriented monetary policy instruments are appropriate. Use of such instruments would improve the ability to finetune monetary policy, increase the efficiency of credit allocation by relying on price signals instead of more direct intervention, and foster creation of a secondary market for government securities, which will be an important building block for developing the domestic capital market.

41. Managed carefully, further relaxation of exchange controls would contribute to capital market development and economic efficiency. This process should be gradual and well supported by a strong policy framework, including adequate international reserves, a solid macroeconomic policy framework, and a strong financial regulatory and prudential framework. 
42. The financial system remains sound and well-regulated. Significant strides have been made in strengthening the supervisory and regulatory framework of the financial system. This should continue to inspire confidence and support further growth in the financial services sector. Particularly welcome are the improvements in the AML/CFT regime, following the introduction of a risk-based approach to monitoring.

43. Economic statistics have improved, although gaps remain. The Department of Statistics should press ahead with its ambitious work program to update and extend the data sets for the analysis of economic and social developments, beyond the two main islands. Despite notable improvements, statistical deficiencies continue to hamper policy assessment, particularly in the national accounts, the balance of payments, debt, and the consolidated public sector.

44. It is proposed that the next Article IV consultation with The Bahamas take place on the standard 24-month cycle. 
Table 1. The Bahamas: Selected Economic Indicators

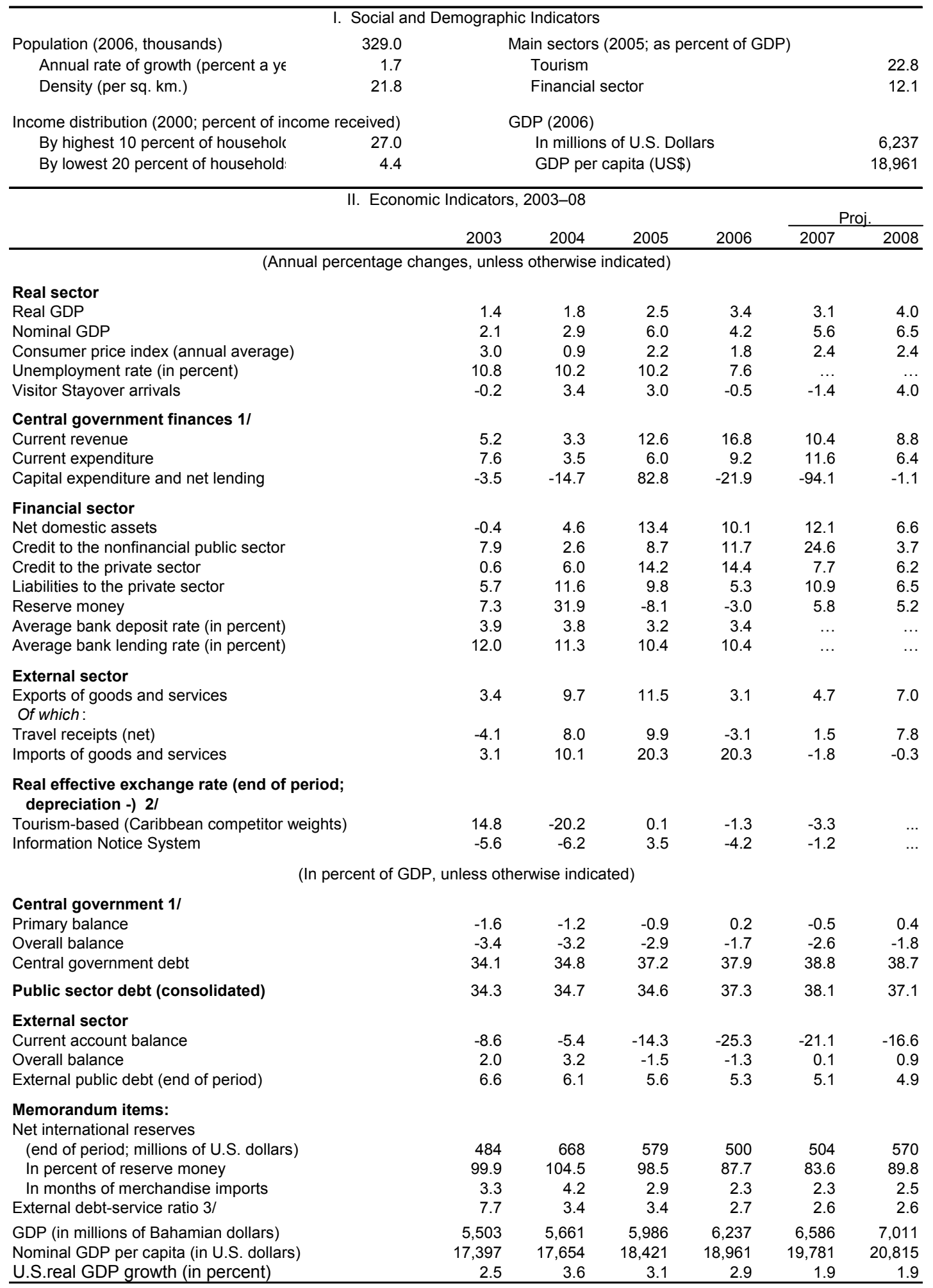

Sources: Central Bank of The Bahamas; Department of Statistics; Ministry of Finance; and Fund staff estimates and projections.

$1 /$ Corresponds to the fiscal year ending June 30 .

2/ For 2007 through May.

$3 /$ In percent of exports of goods and services. 
Table 2. The Bahamas: Operations of the Central Government 1/

\begin{tabular}{|c|c|c|c|c|c|c|}
\hline & FY 02/03 & FY 03/04 & FY 04/05 & FY 05/06 & FY 06/07 & $\begin{array}{r}\text { Proj. } \\
\text { FY 07/08 }\end{array}$ \\
\hline & \multicolumn{6}{|c|}{ (In million of $\mathrm{B} \$$ ) } \\
\hline Revenue 2/ & 899 & 929 & 1,045 & 1,221 & 1,349 & 1,467 \\
\hline Tax revenue & 812 & 831 & 925 & 1,094 & 1,211 & 1,321 \\
\hline Taxes on international trade & 527 & 519 & 538 & 637 & 688 & 711 \\
\hline Tourism taxes & 82 & 94 & 94 & 103 & 88 & 91 \\
\hline Miscellaneous taxes & 203 & 216 & 294 & 322 & 392 & 466 \\
\hline Other & 0 & 2 & -1 & 33 & 42 & 52 \\
\hline Nontax revenue & 87 & 98 & 104 & 126 & 138 & 146 \\
\hline Grants and capital revenue & 0 & 0 & 16 & 1 & 0 & 0 \\
\hline Total expenditure & 1,087 & 1,110 & 1,215 & 1,328 & 1,517 & 1,588 \\
\hline Current expenditure & 960 & 994 & 1,053 & 1,150 & 1,283 & 1,365 \\
\hline Wages and salaries $3 /$ & 511 & 554 & 575 & 622 & 675 & 721 \\
\hline Goods and services 3/ & 253 & 214 & 229 & 255 & 260 & 270 \\
\hline Interest payments & 101 & 113 & 117 & 117 & 136 & 148 \\
\hline Subsidies and transfers $3 /$ & 95 & 113 & 131 & 156 & 212 & 226 \\
\hline Current balance & -61 & -65 & -24 & 71 & 66 & 102 \\
\hline Capital expenditure & 127 & 116 & 162 & 178 & 234 & 223 \\
\hline Capital formation & 79 & 76 & 88 & 120 & 230 & 220 \\
\hline Capital transfers and net lending & 47 & 40 & 74 & 58 & 3 & 3 \\
\hline Overall balance & -188 & -181 & -170 & -106 & -168 & -121 \\
\hline Financing & 188 & 181 & 170 & 106 & 168 & 121 \\
\hline Foreign financing & 1 & 197 & -5 & 1 & 6 & 2 \\
\hline Domestic financing & 186 & -16 & 164 & 105 & 162 & 119 \\
\hline \multicolumn{7}{|l|}{ Memorandum items: } \\
\hline Sale of assets & 0 & 18 & 11 & 1 & 0 & 0 \\
\hline Primary balance & -87 & -68 & -52 & 11 & -32 & 27 \\
\hline Central government debt & 1,855 & 1,941 & 2,168 & 2,319 & 2,487 & 2,616 \\
\hline
\end{tabular}

Sources: Ministry of Finance; and Fund staff estimates and projections.

$1 /$ Fiscal year ends June 30.

2/ Includes in FY 2004/05 tax arrears from the sale of the Hotel Corporation equivalent to 0.3 percent of GDP.

3/ Reclassifies central government transfers to the Public Hospitals Authority (PHA), College of The Bahamas, the Public Utilities commission, and the Ministry of Tourism in wages and purchases of goods and services. 


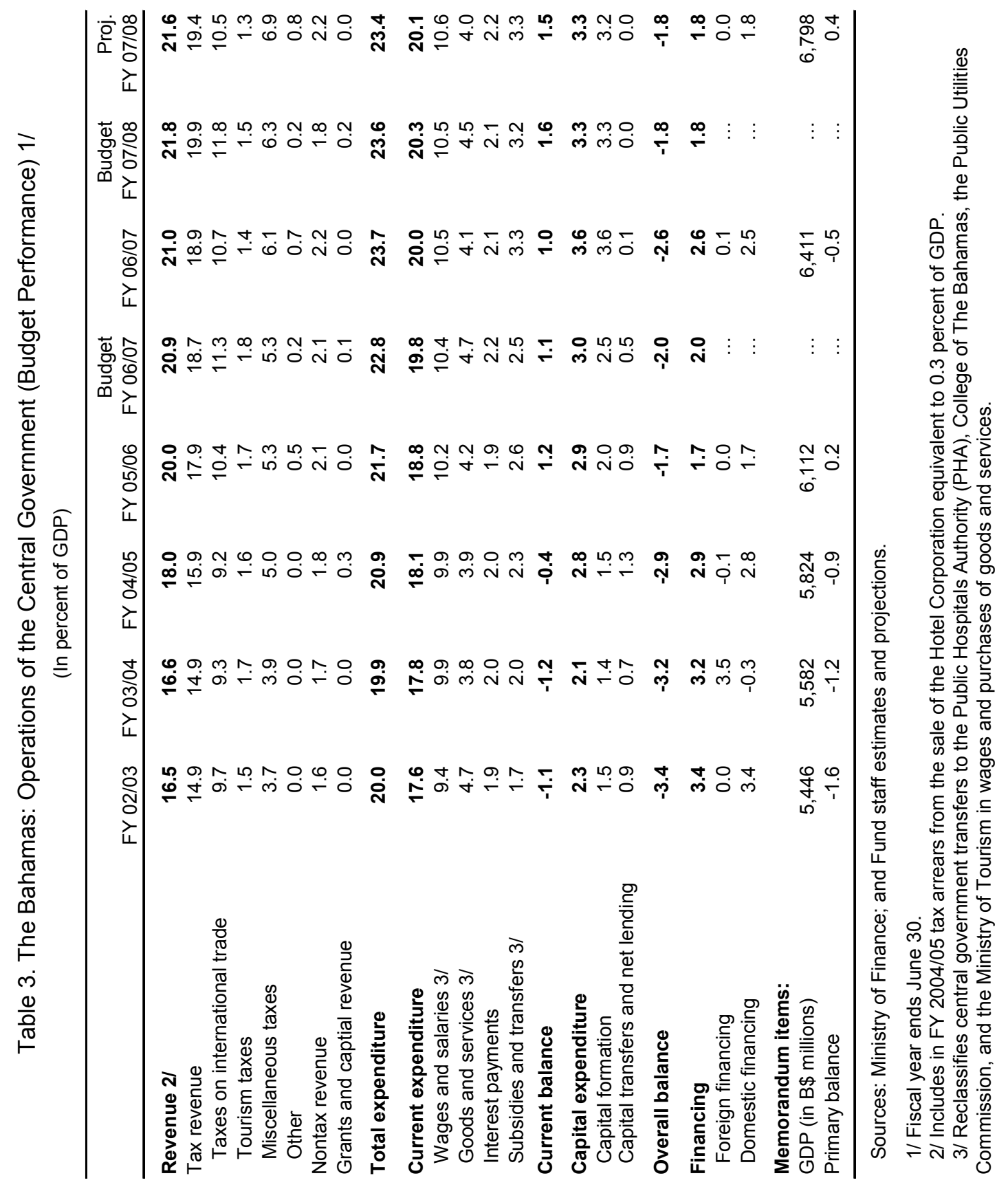


Table 4. The Bahamas: Operations of Nonfinancial Public Corporations 1/

(In percent of GDP)

\begin{tabular}{|c|c|c|c|c|c|c|}
\hline & \multirow[b]{2}{*}{2003} & \multirow[b]{2}{*}{2004} & \multirow[b]{2}{*}{2005} & \multirow{2}{*}{$\begin{array}{l}\text { Prel. } \\
2006\end{array}$} & \multicolumn{2}{|c|}{ Proj. } \\
\hline & & & & & 2007 & 2008 \\
\hline \multicolumn{7}{|c|}{ I. Operations of the Nonfinancial Public Corporations 1/ } \\
\hline Total revenue & 12.0 & 12.7 & 12.9 & 13.4 & 13.6 & 13.4 \\
\hline Current revenue & 11.3 & 12.0 & 12.0 & 12.3 & 12.5 & 12.4 \\
\hline Of which: operating revenue & 11.3 & 12.0 & 12.0 & 12.3 & 12.5 & 12.4 \\
\hline Other & 0.0 & 0.0 & 0.0 & 0.0 & 0.0 & 0.0 \\
\hline Capital revenue & 0.7 & 0.7 & 0.9 & 1.1 & 1.0 & 1.0 \\
\hline Total expenditure & 11.3 & 12.4 & 12.7 & 14.3 & 14.3 & 13.2 \\
\hline Current expenditure & 9.5 & 10.3 & 10.5 & 10.4 & 10.4 & 10.3 \\
\hline Of which: operating expenditure & 8.9 & 9.8 & 10.1 & 10.0 & 9.9 & 9.8 \\
\hline Interest payments & 0.5 & 0.3 & 0.3 & 0.4 & 0.4 & 0.4 \\
\hline Capital expenditure & 1.9 & 2.1 & 2.1 & 3.9 & 3.9 & 2.9 \\
\hline Operating balance & 2.4 & 2.1 & 1.9 & 2.3 & 2.6 & 2.6 \\
\hline Current account balance & 1.9 & 1.7 & 1.5 & 2.0 & 2.2 & 2.1 \\
\hline Overall balance & 0.6 & 0.3 & 0.2 & -0.9 & -0.7 & 0.2 \\
\hline Statistical adjustment & -0.7 & 0.0 & 0.1 & 0.0 & 0.0 & 0.0 \\
\hline Overall balance, adjusted & -0.1 & 0.3 & 0.3 & -0.8 & -0.7 & 0.2 \\
\hline Total financing & 0.1 & -0.3 & -0.3 & 0.8 & 0.7 & -0.2 \\
\hline External financing & -2.6 & -0.3 & 0.0 & 0.0 & 0.0 & 0.0 \\
\hline Domestic financing & 2.7 & 0.0 & -0.3 & 0.9 & 0.7 & -0.2 \\
\hline \multicolumn{7}{|c|}{ II. Operations of the National Insurance Board (NIB) } \\
\hline Revenue & 3.5 & 3.4 & 3.5 & 3.6 & 3.6 & 3.6 \\
\hline Contributions & 2.2 & 2.2 & 2.3 & 2.4 & 2.4 & 2.4 \\
\hline Investment income & 1.2 & 1.1 & 1.2 & 1.2 & 1.2 & 1.1 \\
\hline Transfers from central government & 0.1 & 0.1 & 0.1 & 0.1 & 0.1 & 0.1 \\
\hline Expenditure & 2.5 & 2.8 & 2.4 & 2.9 & 2.9 & 2.8 \\
\hline Current & 2.3 & 2.5 & 2.4 & 2.5 & 2.5 & 2.5 \\
\hline Wages and salaries & 0.2 & 0.3 & 0.2 & 0.2 & 0.2 & 0.2 \\
\hline Benefit payments & 1.9 & 2.0 & 2.0 & 2.0 & 2.0 & 2.0 \\
\hline Goods and services & 0.2 & 0.2 & 0.2 & 0.3 & 0.3 & 0.3 \\
\hline Capital & 0.2 & 0.2 & 0.0 & 0.4 & 0.4 & 0.2 \\
\hline Operating balance & -0.1 & -0.3 & -0.1 & -0.1 & -0.1 & -0.1 \\
\hline Current account balance & 1.2 & 0.9 & 1.1 & 1.1 & 1.1 & 1.0 \\
\hline Overall balance & 1.0 & 0.7 & 1.1 & 0.7 & 0.7 & 0.8 \\
\hline
\end{tabular}

Sources: Ministry of Finance; public corporations; National Insurance Board; and Fund staff estimates and projections.

1/ BTC, Bahamas Electricity, Water and Sewerage, Bahamasair, and Broadcasting Corporations. 
Table 5. The Bahamas: Public Sector Debt

(In percent of GDP)

\begin{tabular}{|c|c|c|c|c|c|c|}
\hline & \multirow[b]{2}{*}{2003} & \multirow[b]{2}{*}{2004} & \multirow[b]{2}{*}{2005} & \multirow[b]{2}{*}{2006} & \multicolumn{2}{|c|}{ Proj. } \\
\hline & & & & & 2007 & 2008 \\
\hline $\begin{array}{l}\text { Total non-financial public sector } \\
\text { (incl. non-guaranteed debt) }\end{array}$ & 49.9 & 50.2 & 49.2 & 53.2 & 54.8 & $\ldots$ \\
\hline External & 6.8 & 6.1 & 5.6 & 5.3 & 5.1 & $\ldots$ \\
\hline Domestic & 43.0 & 44.1 & 43.6 & 47.9 & 49.7 & $\ldots$ \\
\hline Of which: in foreign currency & 6.2 & 5.5 & 4.4 & 7.1 & 8.3 & $\ldots$ \\
\hline Central government debt & 35.2 & 37.1 & 37.3 & 38.2 & 38.8 & 37.9 \\
\hline External & 5.2 & 5.0 & 4.8 & 4.6 & 4.5 & 4.2 \\
\hline Domestic & 29.9 & 32.0 & 32.6 & 33.6 & 34.3 & 33.7 \\
\hline Of which: in foreign currency & 0.0 & 0.0 & 0.0 & 0.0 & 0.0 & 0.0 \\
\hline Public corporations' debt $1 /$ & 11.3 & 10.3 & 10.0 & 11.4 & 11.8 & 11.4 \\
\hline External & 1.4 & 1.0 & 0.8 & 0.7 & 0.7 & 0.7 \\
\hline Domestic & 10.0 & 9.3 & 9.2 & 10.7 & 11.1 & 10.7 \\
\hline Of which: in foreign currency & 4.6 & 4.2 & 3.6 & 4.8 & 5.5 & 5.6 \\
\hline Consolidated public sector $1 /$ & 34.3 & 34.7 & 34.6 & 37.3 & 38.1 & 37.1 \\
\hline External & 6.6 & 6.1 & 5.6 & 5.3 & 5.1 & 4.9 \\
\hline Domestic & 27.7 & 28.7 & 29.0 & 32.0 & 32.9 & 32.2 \\
\hline Of which: in foreign currency & 4.6 & 4.2 & 3.6 & 4.8 & 5.5 & 5.6 \\
\hline \multicolumn{7}{|l|}{ Memorandum items: } \\
\hline Bahamas Electricity Corporation & 4.5 & 3.9 & 3.3 & 3.9 & 4.0 & 3.9 \\
\hline Bahamas Telecommunication Company & 0.9 & 0.6 & 0.4 & 1.2 & 1.8 & 1.8 \\
\hline Financial public sector debt $2 /$ & 2.9 & 2.8 & 3.2 & 3.4 & 3.2 & 3.0 \\
\hline
\end{tabular}

Source: Central Bank of The Bahamas.

1/ Government-guaranteed debt only.

2/ Debt of The Bahamas Mortgage Corporation and The Bahamas Development Bank, included in the total debt of the public sector. 
Table 6. The Bahamas: Selected Indicators of Tourism

\begin{tabular}{|c|c|c|c|c|c|c|}
\hline & 2001 & 2002 & 2003 & 2004 & 2005 & 2006 \\
\hline \multicolumn{7}{|c|}{ (In thousands) } \\
\hline \multicolumn{7}{|l|}{ Stayover arrivals $1 /$} \\
\hline The Bahamas & 1,538 & 1,513 & 1,510 & 1,561 & 1,608 & 1,600 \\
\hline Of which: from the U.S. & 1,308 & 1,310 & 1,305 & 1,361 & 1,380 & 1,364 \\
\hline Caribbean 2/ & 16,384 & 15,696 & 16,767 & 17,903 & 18,618 & 18,352 \\
\hline English-speaking Caribbean 3/ & 7,470 & 7,286 & 7,393 & 7,916 & 8,196 & 8,327 \\
\hline \multicolumn{7}{|c|}{ (Percent change) } \\
\hline The Bahamas & -0.4 & -1.6 & -0.2 & 3.4 & 3.0 & -0.5 \\
\hline Caribbean & -2.6 & -4.2 & 6.8 & 6.8 & 4.0 & -1.4 \\
\hline English-speaking Caribbean & -2.2 & -2.5 & 1.5 & 7.1 & 3.5 & 1.6 \\
\hline \multicolumn{7}{|l|}{ The Bahamas' share in stayover arrivals } \\
\hline Caribbean (percent) & 9.4 & 8.9 & 8.5 & 8.1 & 8.1 & 8.1 \\
\hline Percent change & 2.3 & -4.8 & -4.7 & -4.9 & 0.4 & -0.1 \\
\hline English-speaking Caribbean (percent) & 20.6 & 19.3 & 19.3 & 18.3 & 18.5 & 17.9 \\
\hline Percent change & 1.8 & -6.5 & 0.4 & -5.2 & 0.9 & -3.1 \\
\hline \multicolumn{7}{|c|}{ (In thousands) } \\
\hline \multicolumn{7}{|l|}{ Cruise passenger arrivals } \\
\hline The Bahamas & 2,552 & 2,802 & 2,970 & 3,360 & 3,350 & 3,076 \\
\hline Caribbean & 14,892 & 15,825 & 17,420 & 19,464 & 18,224 & 18,416 \\
\hline \multicolumn{7}{|c|}{ (Percent change) } \\
\hline The Bahamas & 1.6 & 9.8 & 6.0 & 13.1 & -0.3 & -8.2 \\
\hline Caribbean & 2.4 & 6.3 & 10.1 & 11.7 & -6.4 & 1.1 \\
\hline Percent change in market share & -2.4 & -5.9 & -3.7 & 1.2 & 6.5 & -9.1 \\
\hline \multicolumn{7}{|l|}{ Visitors expenditure } \\
\hline \multicolumn{7}{|c|}{ (In millions of U.S. dollars) } \\
\hline The Bahamas & 1,648 & 1,760 & 1,758 & 1,885 & 2,069 & 2,056 \\
\hline Caribbean & 19,489 & 18,779 & 20,060 & 21,636 & $\ldots$ & $\ldots$ \\
\hline English-speaking Caribbean & 10,266 & 10,005 & 10,422 & 11,337 & $\ldots$ & \\
\hline \multicolumn{7}{|c|}{ (In percent) } \\
\hline The Bahamas' share of Caribbean & 8.5 & 9.4 & 8.8 & 8.7 & $\ldots$ & $\ldots$ \\
\hline The Bahamas' share of English-speaking Caribb & 16.0 & 17.6 & 16.9 & 16.6 & $\ldots$ & $\ldots$ \\
\hline \multicolumn{7}{|l|}{ Memorandum items: } \\
\hline \multicolumn{7}{|c|}{ (change in percent) } \\
\hline Tourist arrivals from the U.S. to the Caribbean & -2.2 & -1.0 & 5.3 & 7.3 & -0.8 & 1.2 \\
\hline Real GDP, U.S. & 0.3 & 1.9 & 3.0 & 3.6 & 3.1 & 2.9 \\
\hline Worldwide tourist arrivals $4 /$ & -0.3 & 2.8 & -1.7 & 10.0 & $\ldots$ & $\ldots$ \\
\hline
\end{tabular}

Sources: Caribbean Tourism Statistical Report, 2002-03, Caribbean Tourism Organization (CTO); and Ministry of Tourism.

1/For Cancun, Cozumel, and Puerto Rico, data for 2004 concern nonresident hotel registrations only. 2/ Includes Cancun and Cozumel (Mexico).

3/ Commonwealth Caribbean countries and U.S. territories.

4/ Stayover arrivals as estimated by World Tourism Organization. 
Table 7. The Bahamas: Balance of Payments

\begin{tabular}{|c|c|c|c|c|c|c|}
\hline & \multirow[b]{2}{*}{2003} & \multirow[b]{2}{*}{2004} & \multirow[b]{2}{*}{2005} & \multirow[b]{2}{*}{2006} & \multicolumn{2}{|c|}{ Proj. } \\
\hline & & & & & 2007 & 2008 \\
\hline \multicolumn{7}{|c|}{ (In millions of U.S. dollars) } \\
\hline Current account & -472 & -305 & -856 & $-1,578$ & $-1,392$ & $-1,161$ \\
\hline Trade balance & $-1,331$ & $-1,428$ & $-1,850$ & $-1,932$ & $-1,945$ & $-1,999$ \\
\hline Exports & 427 & 477 & 549 & 692 & 722 & 774 \\
\hline Imports & 1,757 & 1,905 & 2,399 & 2,624 & 2,668 & 2,773 \\
\hline Services (net) & 962 & 1,013 & 1,112 & 520 & 761 & 1,057 \\
\hline Travel & 1,453 & 1,569 & 1,725 & 1,671 & 1,696 & 1,828 \\
\hline Construction services & -38 & -23 & -41 & -214 & -170 & -100 \\
\hline Insurance & -106 & -82 & -97 & -119 & -121 & -128 \\
\hline Other services & -347 & -451 & -16 & -18 & -19 & -20 \\
\hline Income (net) & -152 & -141 & -203 & -218 & -261 & -278 \\
\hline Of which: interests and dividends & -96 & -78 & -130 & -125 & -163 & -178 \\
\hline Current transfers & 49 & 251 & 85 & 52 & 53 & 58 \\
\hline Capital and financial account & 498 & 311 & 633 & 1,159 & 1,397 & 1,227 \\
\hline Capital transfers & -37 & -48 & -60 & -64 & -67 & -71 \\
\hline Long-term public sector & 53 & -21 & -9 & -4 & 8 & 5 \\
\hline Disbursements & 207 & 6 & 5 & 6 & 44 & 19 \\
\hline Amortization & -154 & -26 & -13 & -11 & -36 & -14 \\
\hline Financial system & -102 & -65 & 48 & 143 & 95 & 95 \\
\hline Direct investment & 190 & 274 & 564 & 706 & 700 & 570 \\
\hline Other private capital & 395 & 170 & 91 & 378 & 660 & 629 \\
\hline Net errors and omissions & 85 & 178 & 134 & 340 & 0 & 0 \\
\hline Change in net international & & & & & & \\
\hline reserves (increase -) & -111 & -184 & 89 & 79 & -4 & -66 \\
\hline \multicolumn{7}{|c|}{ (In percent of GDP) } \\
\hline Current account & -8.6 & -5.4 & -14.3 & -25.3 & -21.1 & -16.6 \\
\hline Trade balance & -24.2 & -25.2 & -30.9 & -31.0 & -29.5 & -28.5 \\
\hline Exports & 7.8 & 8.4 & 9.2 & 11.1 & 11.0 & 11.0 \\
\hline Imports & 31.9 & 33.7 & 40.1 & 42.1 & 40.5 & 39.6 \\
\hline Services (net) & 17.5 & 17.9 & 18.6 & 8.3 & 11.6 & 15.1 \\
\hline Of which: travel receipts & 26.4 & 27.7 & 28.8 & 26.8 & 25.7 & 26.1 \\
\hline Income (net) & -2.8 & -2.5 & -3.4 & -3.5 & -4.0 & -4.0 \\
\hline Current transfers & 0.9 & 4.4 & 1.4 & 0.8 & 0.8 & 0.8 \\
\hline Capital and financial account & 9.1 & 5.5 & 10.6 & 18.6 & 21.2 & 17.5 \\
\hline Capital transfers & -0.7 & -0.8 & -1.0 & -1.0 & -1.0 & -1.0 \\
\hline Long-term public sector & 1.0 & -0.4 & -0.1 & -0.1 & 0.1 & 0.1 \\
\hline Financial system & -1.9 & -1.1 & 0.8 & 2.3 & 1.4 & 1.4 \\
\hline Direct investment & 3.5 & 4.8 & 9.4 & 11.3 & 10.6 & 8.1 \\
\hline Portfolio investment & 0.0 & 0.0 & 0.0 & 0.0 & 0.0 & 0.0 \\
\hline Other private capital & 7.2 & 3.0 & 1.5 & 6.1 & 10.0 & 9.0 \\
\hline Net errors and omissions & 1.5 & 3.2 & 2.2 & 5.4 & 0.0 & 0.0 \\
\hline Change in net international & & & & & & \\
\hline reserves (increase -) & -2.0 & -3.2 & 1.5 & 1.3 & -0.1 & -0.9 \\
\hline \multicolumn{7}{|l|}{ Net international reserves } \\
\hline (end of period; millions of US\$) & 484 & 668 & 579 & 500 & 504 & 570 \\
\hline In percent of reserve money & 99.9 & 104.5 & 98.5 & 87.7 & 83.6 & 89.8 \\
\hline In months of merchandise imports & 3.3 & 4.2 & 2.9 & 2.3 & 2.3 & 2.5 \\
\hline In months of next year's imports of G\&S & 1.9 & 2.1 & 1.5 & 1.3 & 1.4 & 1.5 \\
\hline
\end{tabular}

Sources: Central Bank, Department of Statistics; and Fund staff estimates. 
Table 8. The Bahamas: Summary Accounts of the Central Bank and the Financial System

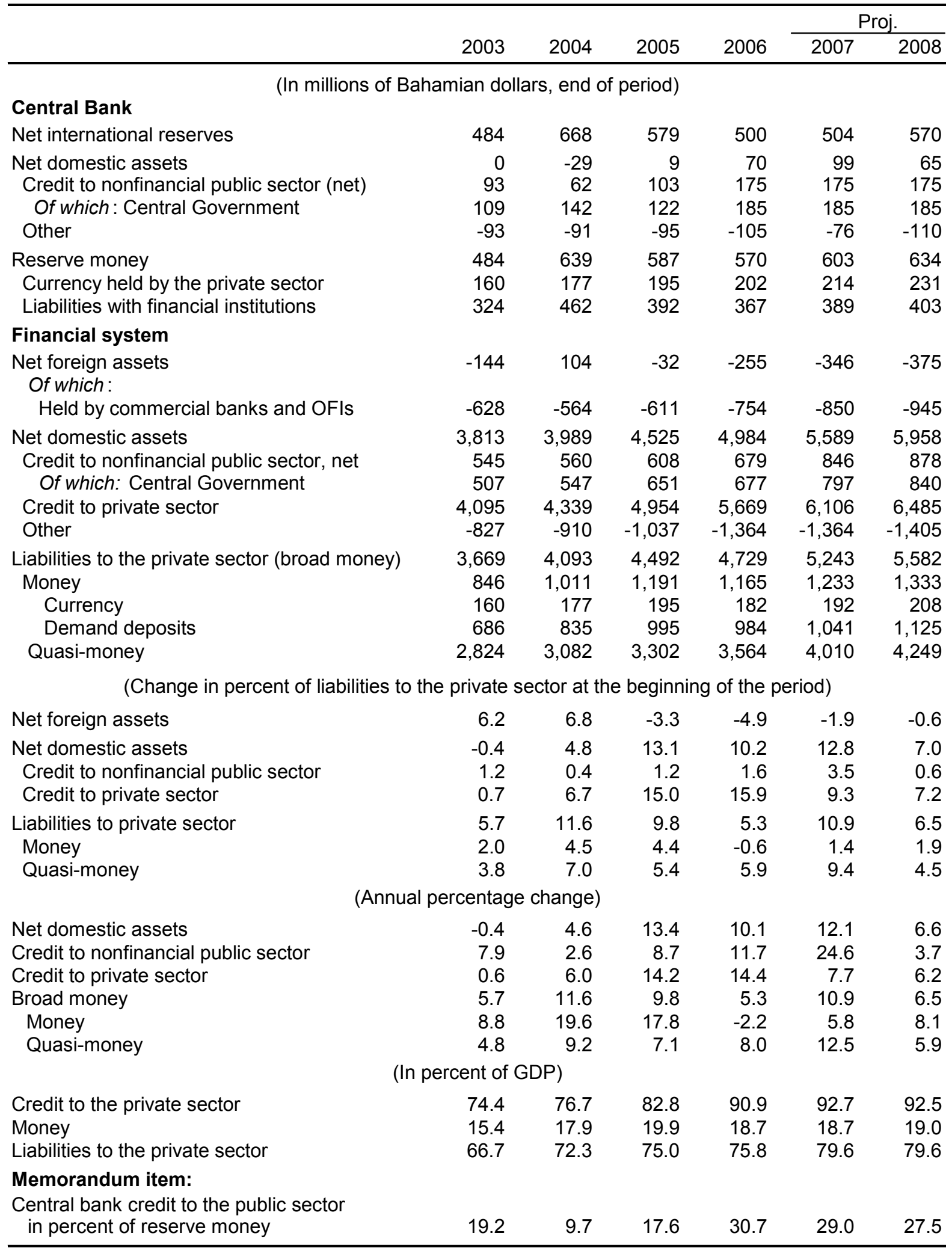

Sources: Central Bank of The Bahamas; and Fund staff estimates and projections. 
Table 9. The Bahamas: Commercial Bank Performance Indicators, 2002-06

(In percent at end-period, unless otherwise noted)

\begin{tabular}{|c|c|c|c|c|c|}
\hline & 2002 & 2003 & 2004 & 2005 & 2006 \\
\hline \multicolumn{6}{|l|}{ Size, dollarization and maturity structure } \\
\hline Total assets, percent of GDP & 105.5 & 108.6 & 113.9 & 117.8 & 125.0 \\
\hline Assets in foreign currency, percent of total assets & 13.0 & 11.6 & 10.5 & 10.2 & 8.3 \\
\hline Foreign currency deposits, percent of total deposits & 2.5 & 2.6 & 2.4 & 3.1 & 2.6 \\
\hline $\begin{array}{l}\text { Deposits maturing within } 3 \text { months, } \\
\text { percent of total deposits }\end{array}$ & 28.9 & 27.3 & 24.2 & 22.3 & 21.4 \\
\hline \multicolumn{6}{|l|}{ Asset quality } \\
\hline Nonperforming loans, percent of total loans & 4.1 & 5.3 & 4.9 & 4.5 & 4.2 \\
\hline Provisions, percent of total loans & 1.7 & 1.9 & 2.0 & 1.6 & 2.3 \\
\hline Provisions, percent of nonperforming loans & 31.0 & 40.2 & 45.0 & 44.9 & 54.2 \\
\hline \multicolumn{6}{|l|}{ Profitability } \\
\hline Pretax return, percent of average assets & 2.6 & 1.8 & 2.7 & 3.6 & 4.0 \\
\hline Pre-tax net revenue, percent of net worth & 21.0 & 11.8 & 15.0 & 19.6 & 20.4 \\
\hline \multicolumn{6}{|l|}{ Liquidity } \\
\hline Liquid assets, percent of total deposits & 18.8 & 20.3 & 21.9 & 19.7 & 17.2 \\
\hline Loans, percent of total deposits & 101.5 & 100.3 & 99.0 & 102.2 & 121.3 \\
\hline \multicolumn{6}{|l|}{ Capital adequacy ratios } \\
\hline Ratio of capital to risk-weighted assets & 29.1 & 23.2 & 35.5 & 30.6 & 33.9 \\
\hline \multicolumn{6}{|l|}{ Interest rates } \\
\hline Lending rate, percent & 11.3 & 12.0 & 11.3 & 10.4 & 10.0 \\
\hline Deposit rate, percent & 4.1 & 3.9 & 3.8 & 3.2 & 3.4 \\
\hline Average interest rate spread, percentage points & 7.2 & 8.1 & 7.5 & 7.1 & 6.6 \\
\hline
\end{tabular}


Table 10. The Bahamas: Indicators of External and Financial Vulnerability

\begin{tabular}{|c|c|c|c|c|c|}
\hline & 2003 & 2004 & 2005 & 2006 & $\begin{array}{l}\text { Proj. } \\
2007\end{array}$ \\
\hline \multicolumn{6}{|l|}{ Financial indicators } \\
\hline Broad money (12-month percentage change) & 5.7 & 11.6 & 9.8 & 5.3 & 10.9 \\
\hline Private sector credit (12-month percentage change) & 0.6 & 6.0 & 14.2 & 14.4 & 7.7 \\
\hline Three-month treasury-bill rate (end of period) & 1.6 & 0.3 & 0.4 & 3.0 & $\ldots$ \\
\hline Domestic public debt (in percent of GDP, end of period ) & 39.9 & 41.3 & 41.7 & 44.3 & 45.4 \\
\hline \multicolumn{6}{|l|}{ External indicators } \\
\hline Exports of goods and services (12-month percentage change) & 3.4 & 9.7 & 11.5 & 3.1 & 4.7 \\
\hline Imports of goods and services (12-month percentage change) & 3.1 & 10.1 & 20.3 & 20.3 & -1.8 \\
\hline Current account balance (in percent of GDP) & -8.6 & -5.4 & -14.3 & -25.3 & -21.1 \\
\hline Capital account balance (in percent of GDP) 1/ & 9.1 & 5.5 & 10.6 & 18.6 & 21.2 \\
\hline Net international reserves (end of period, millions of US\$) & 484 & 668 & 579 & 500 & 504 \\
\hline In months of merchandise imports & 3.3 & 4.2 & 2.9 & 2.3 & 2.3 \\
\hline In months of next year's imports of G. and S. & 1.9 & 2.1 & 1.5 & 1.3 & 1.4 \\
\hline In percent of reserve money & 99.9 & 104.5 & 98.5 & 87.7 & 83.6 \\
\hline In percent of broad money & 13.2 & 16.3 & 12.9 & 10.6 & 9.6 \\
\hline $\begin{array}{l}\text { Commercial banks, net foreign assets (end of period, } \\
\text { millions of US\$) }\end{array}$ & -628 & -564 & -611 & -754 & -945 \\
\hline External public debt (in percent of GDP) & 6.6 & 6.1 & 5.6 & 5.3 & 5.1 \\
\hline $\begin{array}{l}\text { External debt service (in percent of exports of goods } \\
\text { and services) }\end{array}$ & 7.7 & 3.4 & 3.4 & 2.7 & 2.6 \\
\hline $\begin{array}{l}\text { Central Government External debt service (in percent } \\
\text { of government revenue) }\end{array}$ & 2.2 & 2.8 & 1.9 & 1.7 & 3.6 \\
\hline REER appreciation (+) (end of period) $2 /$ & -5.6 & -6.2 & 3.5 & -4.2 & $\cdots$ \\
\hline \multicolumn{6}{|l|}{ Banking sector risk indicators } \\
\hline Foreign currency deposits, percent of total deposits & 2.6 & 2.4 & 3.1 & 2.6 & ... \\
\hline Deposits maturing within 3 months, percent of total deposits & 27.3 & 24.2 & 22.3 & 21.4 & $\ldots$ \\
\hline Capital to risk-weighted assets ratio, percent & 23.2 & 35.5 & 30.6 & 33.9 & $\ldots$ \\
\hline $\begin{array}{l}\text { Nonperforming loans to total loans ratio, percent } \\
\text { Provisions to total loans ratio percent }\end{array}$ & $\begin{array}{r}5.3 \\
402\end{array}$ & $\begin{array}{r}4.9 \\
450\end{array}$ & $\begin{array}{r}4.5 \\
449\end{array}$ & $\begin{array}{r}4.2 \\
542\end{array}$ & $\cdots$ \\
\hline Provisions to total loans ratio, percent & $\begin{array}{l}40.2 \\
118\end{array}$ & $\begin{array}{l}45.0 \\
158\end{array}$ & 44.9 & $\begin{array}{l}54.2 \\
20.4\end{array}$ & $\cdots$ \\
\hline $\begin{array}{l}\text { Pre-tax net revenue, percent of net worth } \\
\text { Administrative expenses, percent of total assets }\end{array}$ & 2.8 & 3.1 & 2.9 & $\begin{array}{r}20.4 \\
2.6\end{array}$ & $\begin{array}{l}\cdots \\
\cdots\end{array}$ \\
\hline Liquid assets to deposits ratio, percent & 20.3 & 21.9 & 19.7 & 17.2 & $\ldots$ \\
\hline Average interest rate spread, percent & 8.1 & 7.5 & 7.1 & 6.6 & $\ldots$ \\
\hline
\end{tabular}

Sources: Central Bank of The Bahamas; and Fund staff estimates and projections.

$1 /$ Includes errors and omissions.

2/ Information Notice System. 
Table 11. The Bahamas: Summary Medium-Term Macro Flows: Baseline Scenario

\begin{tabular}{|c|c|c|c|c|c|c|c|c|}
\hline & \multirow[b]{2}{*}{2005} & \multirow[b]{2}{*}{2006} & \multicolumn{6}{|c|}{ Projections } \\
\hline & & & 2007 & 2008 & 2009 & 2010 & 2011 & 2012 \\
\hline \multicolumn{9}{|c|}{ (Annual percentage change) } \\
\hline \multicolumn{9}{|l|}{ National income } \\
\hline GDP at constant prices & 2.5 & 3.4 & 3.1 & 4.0 & 3.8 & 3.8 & 3.8 & 3.8 \\
\hline \multicolumn{9}{|l|}{ Tourism } \\
\hline $\begin{array}{l}\text { Total arrivals } \\
\text { Of which: }\end{array}$ & 0.6 & -6.1 & -1.3 & 4.0 & 3.5 & 3.0 & 3.1 & 3.0 \\
\hline Stayover arrivals & 3.0 & -0.5 & -1.4 & 4.0 & 3.5 & 3.0 & 3.1 & 3.0 \\
\hline \multicolumn{9}{|l|}{ Monetary sector } \\
\hline Liabilities to the private sector (M3) & 9.8 & 5.3 & 10.9 & 6.5 & 6.2 & 6.0 & 5.9 & 6.9 \\
\hline Credit to the private sector & 14.2 & 14.4 & 7.7 & 6.2 & 6.1 & 6.2 & 6.0 & 6.1 \\
\hline \multicolumn{9}{|l|}{ Balance of payments } \\
\hline $\begin{array}{l}\text { Exports of goods and services } \\
\text { Of which: }\end{array}$ & 11.5 & 3.1 & 4.7 & 7.0 & 7.2 & 6.2 & 6.1 & 6.2 \\
\hline Travel receipts (net) & 9.9 & -3.1 & 1.5 & 7.8 & 8.2 & 6.7 & 6.6 & 6.6 \\
\hline Imports of goods and services & 20.3 & 20.3 & -1.8 & -0.3 & 0.3 & 3.0 & 4.0 & 4.4 \\
\hline \multicolumn{9}{|c|}{ (In percent of GDP, unless otherwise indicated) } \\
\hline \multicolumn{9}{|l|}{ Balance of payments } \\
\hline Current account & -14.3 & -25.3 & -21.1 & -16.6 & -12.4 & -10.6 & -9.5 & -8.6 \\
\hline Capital and financial account & 10.6 & 18.6 & 21.2 & 17.5 & 13.5 & 11.6 & 10.5 & 9.2 \\
\hline Public sector (net) 1/ & -1.2 & -1.1 & -0.9 & -0.9 & -1.0 & -1.0 & -1.0 & -1.0 \\
\hline Private sector (net) 2/ & 14.0 & 25.1 & 22.1 & 18.4 & 14.4 & 12.6 & 11.5 & 10.2 \\
\hline Direct investment & 9.4 & 11.3 & 10.6 & 8.1 & 6.6 & 6.0 & 5.8 & 5.7 \\
\hline Other private sector $3 /$ & 4.5 & 13.8 & 11.5 & 10.3 & 7.8 & 6.6 & 5.7 & 4.5 \\
\hline $\begin{array}{l}\text { Change in net international } \\
\text { reserves (increase -) }\end{array}$ & 15 & 13 & -01 & Q & -10 & 10 & 10 & 7 \\
\hline \multicolumn{9}{|l|}{ Central government 4 / } \\
\hline Revenue & 18.0 & 20.0 & 21.0 & 21.6 & 22.1 & 22.4 & 22.7 & 23.1 \\
\hline Expenditure & 20.9 & 21.7 & 23.7 & 23.4 & 23.3 & 23.1 & 23.1 & 23.1 \\
\hline Current & 18.1 & 18.8 & 20.0 & 20.1 & 20.0 & 19.8 & 19.8 & 19.7 \\
\hline Capital & 2.8 & 2.9 & 3.6 & 3.3 & 3.3 & 3.3 & 3.3 & 3.3 \\
\hline Overall balance & -2.9 & -1.7 & -2.6 & -1.8 & -1.1 & -0.7 & -0.4 & 0.1 \\
\hline \multicolumn{9}{|l|}{ Memorandum items: } \\
\hline Central government primary balance 4 / & -0.9 & 0.2 & -0.5 & 0.4 & 1.0 & 1.3 & 1.5 & 1.8 \\
\hline Central government debt (end-June) & 37.2 & 37.9 & 38.8 & 38.7 & 37.5 & 36.0 & 34.1 & 31.9 \\
\hline External public debt service $5 /$ & 3.4 & 2.7 & 2.6 & 2.6 & 4.4 & 1.9 & 1.8 & 1.7 \\
\hline \multicolumn{9}{|l|}{ Gross international reserves } \\
\hline In millions of U.S. dollars & 579 & 500 & 504 & 570 & 646 & 725 & 805 & 864 \\
\hline In percent of reserve money & 98.5 & 87.7 & 83.6 & 89.8 & 95.5 & 100.5 & 104.9 & 105.0 \\
\hline In percent of M2 6/ & 12.9 & 10.6 & 9.6 & 10.2 & 10.9 & 11.5 & 12.1 & 12.1 \\
\hline In months of merchandise imports & 2.9 & 2.3 & 2.3 & 2.5 & 2.8 & 3.0 & 3.2 & 3.3 \\
\hline In months of next year's imports of GS & 1.5 & 1.3 & 1.4 & 1.5 & 1.7 & 1.8 & 1.9 & 1.9 \\
\hline GDP (in millions of Bahamian dollars) & 5,986 & 6,237 & 6,586 & 7,011 & 7,445 & 7,889 & 8,353 & 8,843 \\
\hline
\end{tabular}

Source: Fund staff projections.

$1 /$ Includes capital transfers.

2/ Includes errors and omissions.

3/ Includes financial sector.

4/ Refers to fiscal year ending June 30.

$5 /$ In percent of exports of goods and services.

6/ Liabilities in local currency, including deposits of public corporations. 
Table 12. The Bahamas: Medium-term Balance of Payments

\begin{tabular}{|c|c|c|c|c|c|c|c|c|}
\hline & \multirow[b]{2}{*}{2005} & \multirow[b]{2}{*}{2006} & \multicolumn{6}{|c|}{ Projections } \\
\hline & & & 2007 & 2008 & 2009 & 2010 & 2011 & 2012 \\
\hline \multicolumn{9}{|c|}{ (In millions of U.S. dollars) } \\
\hline Current account & -856 & $-1,578$ & $-1,392$ & $-1,161$ & -925 & -838 & -797 & -757 \\
\hline Trade balance & $-1,850$ & $-1,932$ & $-1,945$ & $-1,999$ & $-1,978$ & $-2,036$ & $-2,116$ & $-2,193$ \\
\hline Exports & 549 & 692 & 722 & 774 & 821 & 861 & 903 & 948 \\
\hline Imports & 2,399 & 2,624 & 2,668 & 2,773 & 2,798 & 2,897 & 3,019 & 3,141 \\
\hline Services (net) & 1,112 & 520 & 761 & 1,057 & 1,276 & 1,433 & 1,572 & 1,706 \\
\hline Travel & 1,725 & 1,671 & 1,696 & 1,828 & 1,978 & 2,110 & 2,249 & 2,397 \\
\hline Construction services & -41 & -214 & -170 & -100 & -80 & -60 & -60 & -60 \\
\hline Insurance & -97 & -119 & -121 & -128 & -135 & -142 & -149 & -156 \\
\hline Other services & -243 & -631 & -457 & -366 & -331 & -323 & -318 & -332 \\
\hline Income (net) & -203 & -218 & -261 & -278 & -286 & -303 & -327 & -348 \\
\hline Of which: interests and dividends & -130 & -125 & -163 & -178 & -186 & -197 & -214 & -229 \\
\hline Current transfers & 85 & 52 & 53 & 58 & 63 & 68 & 73 & 78 \\
\hline Capital and financial account & 633 & 1,159 & 1,397 & 1,227 & 1,001 & 916 & 878 & 816 \\
\hline Capital transfers & -60 & -64 & -67 & -71 & -76 & -80 & -85 & -90 \\
\hline Long-term public sector & -9 & -4 & 8 & 5 & 5 & 5 & 5 & 5 \\
\hline Disbursements & 5 & 6 & 44 & 19 & 20 & 20 & 20 & 20 \\
\hline Amortization & -13 & -11 & -36 & -14 & -15 & -15 & -15 & -15 \\
\hline Financial system & 48 & 143 & 95 & 95 & 95 & 95 & 95 & 95 \\
\hline Direct investment & 564 & 706 & 700 & 570 & 495 & 470 & 485 & 505 \\
\hline Other private capital & 91 & 378 & 660 & 629 & 480 & 425 & 375 & 285 \\
\hline Net errors and omissions & 134 & 340 & 0 & 0 & 0 & 0 & 0 & 0 \\
\hline \multicolumn{9}{|l|}{ Change in net international } \\
\hline reserves (increase -) & 89 & 79 & -4 & -66 & -77 & -78 & -80 & -59 \\
\hline \multicolumn{9}{|c|}{ (In percent of GDP) } \\
\hline Current account & -14.3 & -25.3 & -21.1 & -16.6 & -12.4 & -10.6 & -9.5 & -8.6 \\
\hline Trade balance & -30.9 & -31.0 & -29.5 & -28.5 & -26.6 & -25.8 & -25.3 & -24.8 \\
\hline Exports & 9.2 & 11.1 & 11.0 & 11.0 & 11.0 & 10.9 & 10.8 & 10.7 \\
\hline Imports & 40.1 & 42.1 & 40.5 & 39.6 & 37.6 & 36.7 & 36.1 & 35.5 \\
\hline Services (net) & 18.6 & 8.3 & 11.6 & 15.1 & 17.1 & 18.2 & 18.8 & 19.3 \\
\hline Of which: travel receipts & 28.8 & 26.8 & 25.7 & 26.1 & 26.6 & 26.7 & 26.9 & 27.1 \\
\hline Income (net) & -3.4 & -3.5 & -4.0 & -4.0 & -3.8 & -3.8 & -3.9 & -3.9 \\
\hline Current transfers & 1.4 & 0.8 & 0.8 & 0.8 & 0.8 & 0.9 & 0.9 & 0.9 \\
\hline Capital and financial account & 10.6 & 18.6 & 21.2 & 17.5 & 13.5 & 11.6 & 10.5 & 9.2 \\
\hline Capital transfers & -1.0 & -1.0 & -1.0 & -1.0 & -1.0 & -1.0 & -1.0 & -1.0 \\
\hline Long-term public sector & -0.1 & -0.1 & 0.1 & 0.1 & 0.1 & 0.1 & 0.1 & 0.1 \\
\hline Financial system & 0.8 & 2.3 & 1.4 & 1.4 & 1.3 & 1.2 & 1.1 & 1.1 \\
\hline Direct investment & 9.4 & 11.3 & 10.6 & 8.1 & 6.6 & 6.0 & 5.8 & 5.7 \\
\hline Other private capital & 1.5 & 6.1 & 10.0 & 9.0 & 6.5 & 5.4 & 4.5 & 3.2 \\
\hline Net errors and omissions & 2.2 & 5.4 & 0.0 & 0.0 & 0.0 & 0.0 & 0.0 & 0.0 \\
\hline \multicolumn{9}{|l|}{$\begin{array}{l}\text { Change in net international } \\
\text { reserves (increase -) }\end{array}$} \\
\hline reserves (increase -) & 1.5 & 1.3 & -0.1 & -0.9 & -1.0 & -1.0 & -1.0 & -0.7 \\
\hline \multicolumn{9}{|l|}{ Net international reserves } \\
\hline (end of period; millions of US\$) & 579 & 500 & 504 & 570 & 646 & 725 & 805 & 864 \\
\hline In percent of reserve money & 98.5 & 87.7 & 83.6 & 89.8 & 95.5 & 100.5 & 104.9 & 105.0 \\
\hline In months of merchandise imports & 2.9 & 2.3 & 2.3 & 2.5 & 2.8 & 3.0 & 3.2 & 3.3 \\
\hline In months of next year's imports of G\&S & 1.5 & 1.3 & 1.4 & 1.5 & 1.7 & 1.8 & 1.9 & 2.0 \\
\hline
\end{tabular}

Sources: Central Bank, Department of Statistics; and Fund staff estimates. 


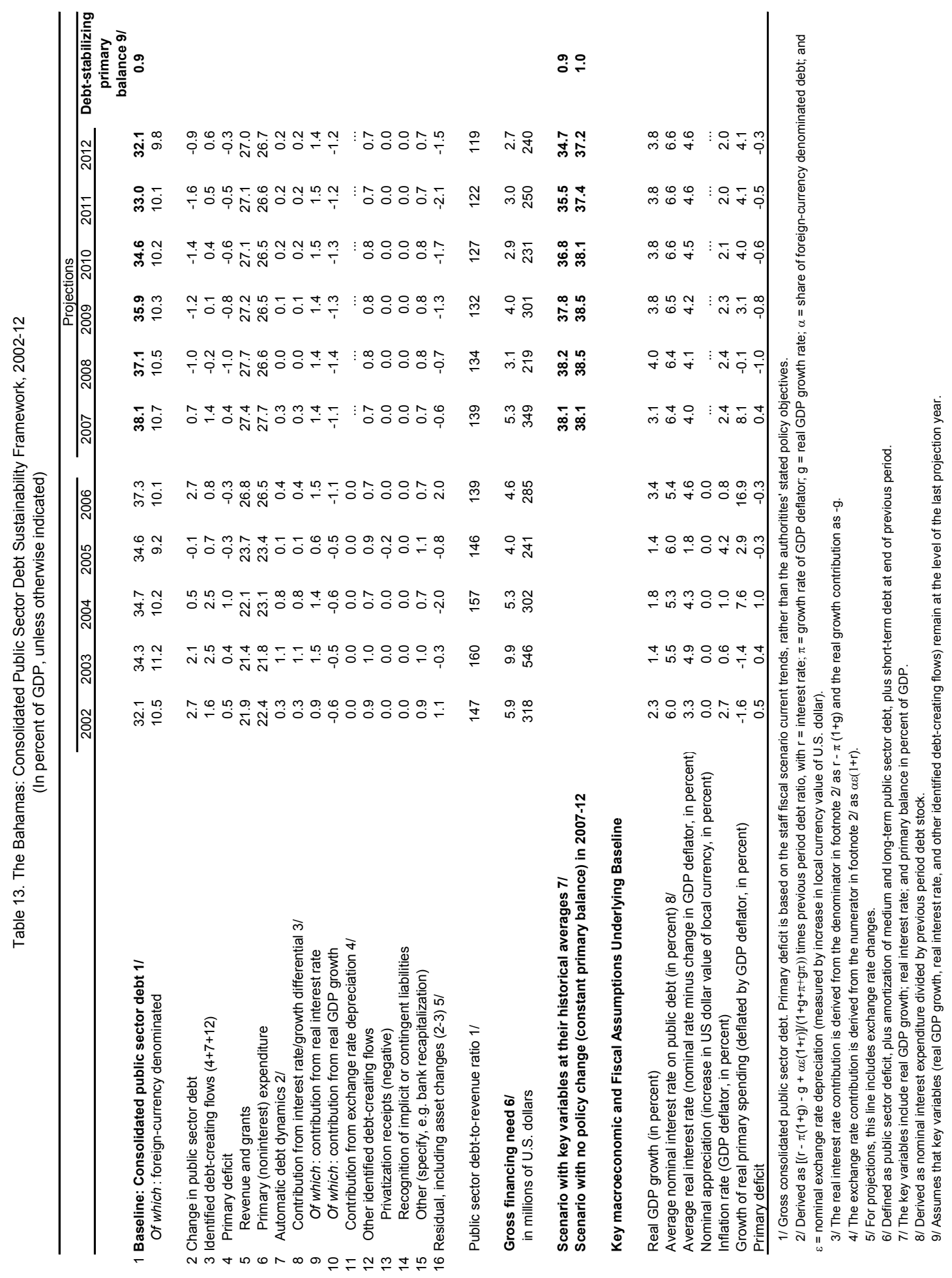




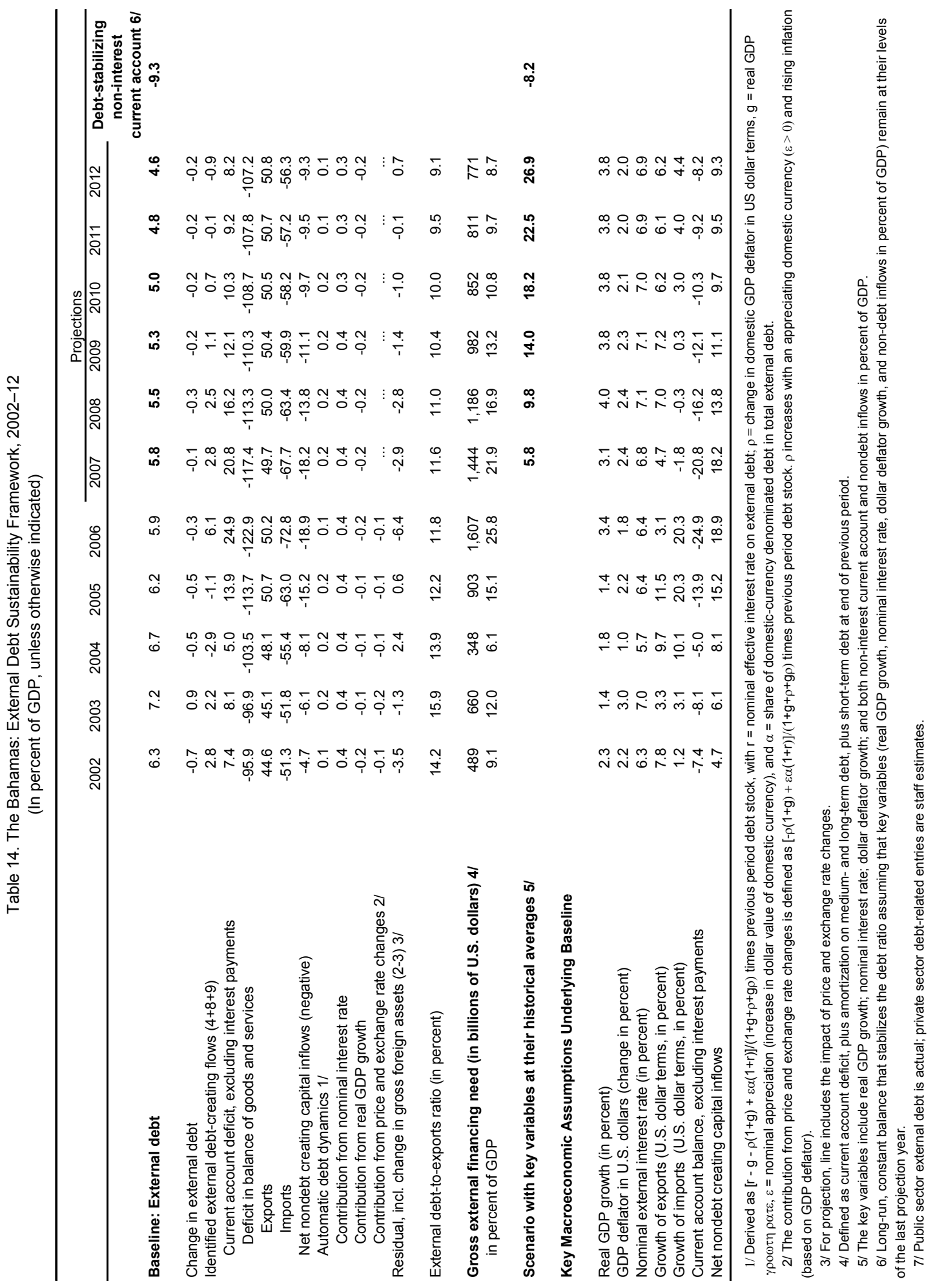




\section{Appendix I. Background and Summary of Appendices}

Discussions. The 2007 Article IV consultation discussions were held in Nassau during September 11-20, 2007. The mission met with Prime Minister Hubert Ingraham, Finance Minister of State Zhivargo Laing, Governor Wendy Craigg, Financial Secretary Ruth Millar, other senior officials, representatives of the private sector, and the opposition. The staff team comprised Trevor Alleyne (Head), Werner Keller, Gil Mehrez, and Elöd Takáts (all WHD). Mr. Ladd (OED) attended the final meeting.

Exchange arrangement. The Bahamas has accepted the obligations of the Article VIII, Sections 2, 3, and 4, and maintains an exchange system that is free of restrictions on payments and transfers for current international transactions. The exchange rate of the Bahamian dollar is pegged to the U.S. dollar at parity.

Fund relations. The Bahamas has no outstanding purchases or loans.

Technical assistance. In 2005, STA provided assistance in balance of payments and external debt accounting, and government finance statistics. In 2007, STA assisted in the compilation of the new national accounts series. Immediately following the 2007 Article IV consultation mission, an MCM/CARTAC mission provided advice on the adoption of market-oriented monetary instruments.

Statistical issues. Data provided to the Fund is adequate for surveillance purposes. Despite significant recent progress in timeliness and quality, weaknesses remain, particularly in the areas of national accounts, the balance of payments, debt, and the consolidated public sector. A new and upgraded series of national accounts is being published, and next year, the series will be rebased and calculated backwards. An ambitious program to conduct comprehensive socio-economic and corporate surveys is being executed, covering for the first time all islands.

Relations with the Inter-American Development Bank (IDB). As of August 23, 2007, the active portfolio of the IDB stood at US\$112 million, of which US\$53 million were outstanding. The 2003-07 country strategy focused on: (i) supporting private sector development; (ii) promoting social development and equity enhancement; (iii) environmental protection and natural resource sustainability; and (iv) improving public sector management. The IDB will prepare a new country strategy for 2008-12. 


\section{Appendix II. The Bahamas-Exchange Rate Assessment ${ }^{1}$}

This note uses the Fundamentals Equilibrium Real Exchange Rate (FEER) approach to assess the real exchange rate in The Bahamas. Panel regression techniques were used to estimate an equilibrium relationship between real exchange rates and a set of fundamentals. The estimated relationship was then used to calculate the equilibrium real exchange rates. The panel includes The Bahamas, the six ECCU countries, Jamaica, Belize, and the Barbados.

\section{Fundamentals}

The FEER emphasizes the time-varying nature of the equilibrium real exchange rate as a function of real factors (fundamentals) that have a role in the determination of equilibrium levels (Edwards, 1999 and CGER, 2006). ${ }^{2}$ In the case of the tourism-dominated economies we expect the real exchange rate to be a function of the following fundamentals:

- Productivity differentials. According to the so-called Balassa-Samuelson effect, higher productivity in tradables will result in a real appreciation of the exchange rate. Per capita tourist arrivals as share of per capita tourist arrivals in Antigua and Barbuda - the country with the second highest per capita arrivals in the region after The Bahamas - were used as a proxy for productivity differentials. ${ }^{3}$

- Terms of trade. Higher terms of trade may appreciate the real exchange rate through wealth effects. Given the dominance of tourism in the region, we use a proxy for tourism terms of trade - movements in the terms of trade of goods and services not explained by movements in terms of trade of goods.

- Government consumption. Higher government consumption is likely to appreciate the real exchange rate to the extent that it falls mostly on non-tradables.

- Net Foreign Assets. Macroeconomic models predict that countries with higher net foreign assets can in principle sustain a stronger real exchange rate because the income flow they receive on their assets.

\footnotetext{
${ }^{1}$ Prepared by Emilio Pineda.

${ }^{2}$ Recent applications of this methodology include Cerra and Saxena (2002), Mathiensen (2003), Abidh and Tsangarides (2006), and CGER (2006).

${ }^{3}$ Other countries — such as Barbados-were used as benchmark with similar results.
} 


\section{Estimation results}

The estimated model found a significant long-run relationship between the real exchange rate and most of the identified fundamentals, particularly tourism-driven productivity and terms of trade. Table 1 presents the panel regressions results for the panel including ECCU countries plus Jamaica, Barbados, The Bahamas and Belize. The estimation results proved robust to different specifications and samples, and are in line with those found in the literature. $^{4}$

- The estimated coefficient for productivity differentials implies that an increase of 10 percent in per capita tourist arrivals relative to the per capita tourist arrivals in Antigua and Barbuda, is associated with an appreciation of around 1 percent in the equilibrium real exchange rate.

- A ten percent increase in the tourism terms of trade is associated with an appreciation of the equilibrium real exchange rate of 2 percent.

- The estimated coefficient for government consumption implies that an increase of 10 percent in government consumption as a share of GDP would be associated with an appreciation of the equilibrium real exchange rate of 14 percent.

Table 1. Results of the Error Correction Specification

Specification

Estimates of the long-run relationship

Government Consumption

$\ln ($ Terms of Trade of Tourism)

$\ln$ (Terms of Trade of Goods)

Productivity

NFA ( $\%$ of GDP)

Constant

Half-life of deviation 2/

Prob $>$ chi2

$\mathrm{N}$

1/OLS-based Panel Corrected Standard Errors assuming cross-sectional correlation, panel heteroskedasticity, and $\mathrm{AR}(1)$ process.

$2 /$ Half-life of deviation is estimated as $-\ln (2) / \ln (r)$ where $r$ is the error correction coefficient.

Coefficients in the parentheses represent the respective $\mathrm{z}$ and $\mathrm{t}$ values. $*, * *, * * *$ denote significance at the 10,5 , and 1 percent, respectively.
SUR 1/

1.39

(3.16)

0.17

(2.49)

$-0.01$

$(-0.12)$

0.06

(2.57)

0.02

$(1.40)$

$1.68 * * *$

1.7

0.0000

10

\section{Equilibrium real exchange rates}

Equilibrium Real Exchange Rates (ERER) were computed by evaluating the relationship between the real exchange rate and the fundamentals. ${ }^{5}$ The figure below shows the evolution of the actual and equilibrium values for the REER in The Bahamas between 1979-2006.

\footnotetext{
${ }^{4}$ For additional robustness checks see Pineda and Cashin (2007), "Is the Eastern Caribbean Dollar Overvalued?," forthcoming Working Paper.

${ }^{5}$ The fundamentals can exhibit a substantial degree of "noise" or fluctuations. To ameliorate the impact of these fluctuations we applied a Hodrick-Prescott filter with a smoothing factor of 10.
} 
The Bahamas: Actual and Equilibrium REER, 1979-2006

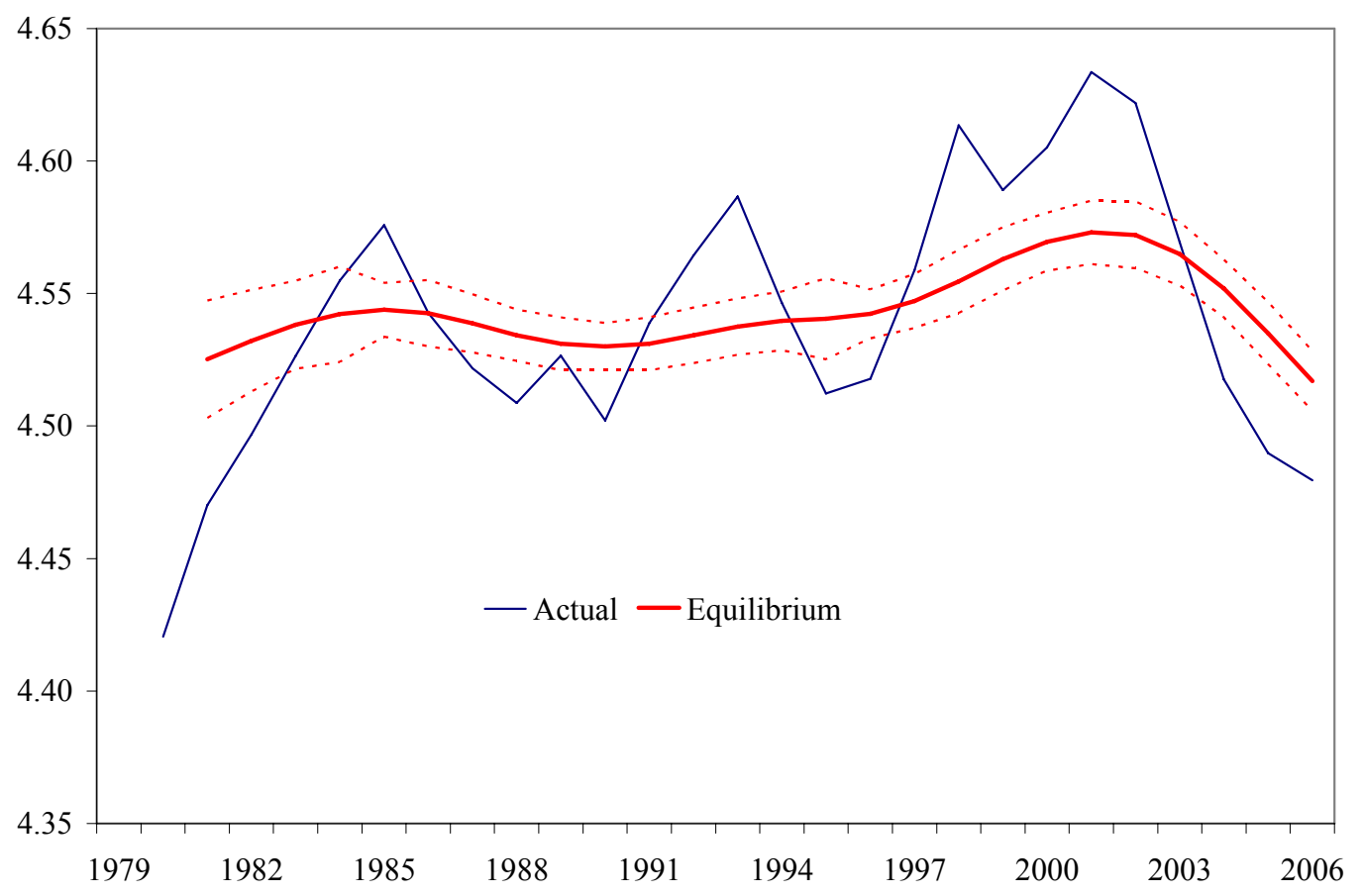




\title{
INTERNATIONAL MONETARY FUND
}

\author{
THE BAHAMAS
}

\section{Staff Report for the 2007 Article IV Consultation-Informational Annex}

\author{
Prepared by the Western Hemisphere Department
}

November 9, 2007

Contents

Page

Annexes

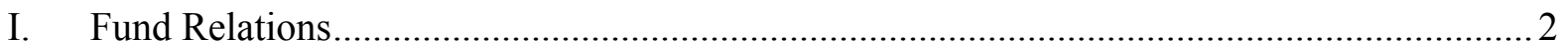

II. Financial Relations with the Inter-American Development Bank ................................... 4

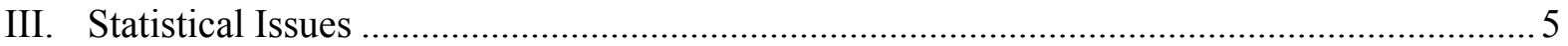




\section{Annex I. The Bahamas-Fund Relations}

(As of September 30, 2007)

I. Membership Status: Joined August 21, 1973; Article VIII.

\section{A. Financial Relations}

II. General Resources Account:

SDR Million

Quota

Fund holdings of currency

Reserve position in the Fund

III. SDR Department:

Net cumulative allocation

Holdings
130.30

124.04

6.26

SDR Million

10.23

0.05
Percent

of Quota

100.00

95.20

4.80

Percent

Allocation

100.0

0.46

IV. Outstanding Purchases and Loans: None

V. Financial Arrangements: None

VI. Projected Obligations to the Fund: (SDR Million; based on existing use of resources and present holdings of SDRs):

Forthcoming

\begin{tabular}{rrrrr}
\hline 2007 & $\mathbf{2 0 0 8}$ & $\mathbf{2 0 0 9}$ & $\mathbf{2 0 1 0}$ & $\mathbf{2 0 1 1}$ \\
\hline & & & & \\
0.10 & 0.39 & 0.39 & 0.39 & 0.39 \\
$\mathbf{0 . 1 0}$ & $\mathbf{0 . 3 9}$ & $\mathbf{0 . 3 9}$ & $\mathbf{0 . 3 9}$ & $\mathbf{0 . 3 9}$
\end{tabular}

\section{B. Nonfinancial Relations}

\section{Exchange Rate Arrangement:}

The Bahamian dollar is pegged to the U.S. dollar at B \$1 per US\$1. The official buying and selling rate is $\mathrm{B} \$ 1.0025$ (buying) and $\mathrm{B} \$ 1.0040$ (selling) per U.S. dollar. In addition, the central bank buys and sells investment currency at premium bid and offer rates of 10 percent and 12.5 percent, respectively. 
The Bahamas has accepted the obligations of Article VIII, Sections 2, 3, and 4 of the Articles of Agreement and maintains an exchange system that is free of restrictions on the making of payments and transfers for current international transactions.

\section{Last Article IV Consultation:}

The Bahamas is on a 24-month consultation cycle. The last Article IV consultation was concluded on June 24, 2005.

\section{Technical Assistance:}

\section{Department}

STA

STA

STA

MCM

\section{Dates}

February 2005

April 2005

July 2007

October 2007

\section{Purpose}

BOP and external debt

Government finance

National accounts

Monetary policy

\section{Resident Representative:}

None. 


\section{Annex II. The Bahamas-Financial Relations with the Inter-American Development Bank (IDB)}

A. Active Loans as of August 23, 2007

(in U.S. dollar millions)

Purpose

Approval

Amount

Date Amount Disbursed

Solid waste management

Infrastructure rehabilitation

$2 / 17 / 1999$

23.5

18.0

New Providence transport program

$9 / 13 / 2000$

19.7

19.7

Land use policy and administration project

$5 / 30 / 2001$

43.4

13.2

Transforming education and training

$11 / 17 / 2004$

3.5

0.7

$11 / 30 / 2005$

18.0

1.4

Masterplan for coastal zone management

$11 / 15 / 2006$

3.8

0.0

Total

111.9

53.0

Source: The Inter-American Development Bank.

B. Net Flow of Convertible Currencies

(in U.S. dollar millions)

\begin{tabular}{lrrrr}
\hline & 2004 & 2005 & 2006 & $\begin{array}{r}\text { Proj. } \\
\end{array}$ \\
& & & & \\
& 3.5 & 35.5 & 8.8 & 14.0 \\
Loan approvals & 4.2 & 5.0 & 7.1 & 12.9 \\
Loan disbursements & 4.4 & 3.6 & 4.9 & 6.7 \\
Repayments (principal) & $\mathbf{- 0 . 2}$ & $\mathbf{1 . 4}$ & $\mathbf{2 . 2}$ & $\mathbf{6 . 2}$ \\
Net loan flow & 3.5 & 3.7 & 3.6 & 4.0 \\
Interest and charges & $\mathbf{- 3 . 7}$ & $\mathbf{- 2 . 3}$ & $\mathbf{- 1 . 5}$ & $\mathbf{2 . 2}$ \\
Net cash flow & & & & \\
\hline
\end{tabular}

Source: The Inter-American Development Bank.

\section{Recent Country Strategy}

The IDB's strategy for 2003-07 has been to focus on: (i) supporting private sector development; (ii) promoting social development and equity enhancement; (iii) environmental protection and natural resource sustainability; and (iv) improving public sector management. A key feature of the strategy has been to focus on relatively small projects with a high technical assistance content. The IDB will prepare a new strategy for 2008-12. 


\section{Annex III. The Bahamas-Statistical Issues}

There has been significant recent progress in the timeliness and quality of economic data, although weaknesses remain. Statistical data are adequate for surveillance purposes. The Department of Statistics (DOS) is publishing a new and upgraded series of national accounts. This year's second edition, covering 2006, became available at a much shortened time lag, but not in time for the FY 2007/08 budget. Next year, the series will be rebased and calculated backwards to 1989 . The central bank produces annual, quarterly, and monthly reports covering macroeconomic developments and summary monetary and fiscal data, and a weekly brief of key monetary data is available to the staff. The operations of public corporations are not compiled into a consolidation of the public sector accounts.

The DOS has an ambitious program to conduct comprehensive socio-economic surveys. (i) A household expenditure survey with a poverty assessment module has been completed; (ii) a survey on social conditions will provide MDG data (modified to fit the local circumstances); (iii) an occupational survey, to be conducted in the fourth quarter 2007, will update the labor force statistics; and (iv) an enterprise census in 2008 will provide a comprehensive inventory of economic activity and will, for the first time, cover the outer islands.

The Bahamas began participation in the General Data Dissemination System (GDDS) in 2003. Its metadata was posted on the Fund's Dissemination Standards Bulletin Board on February 14, 2003. 


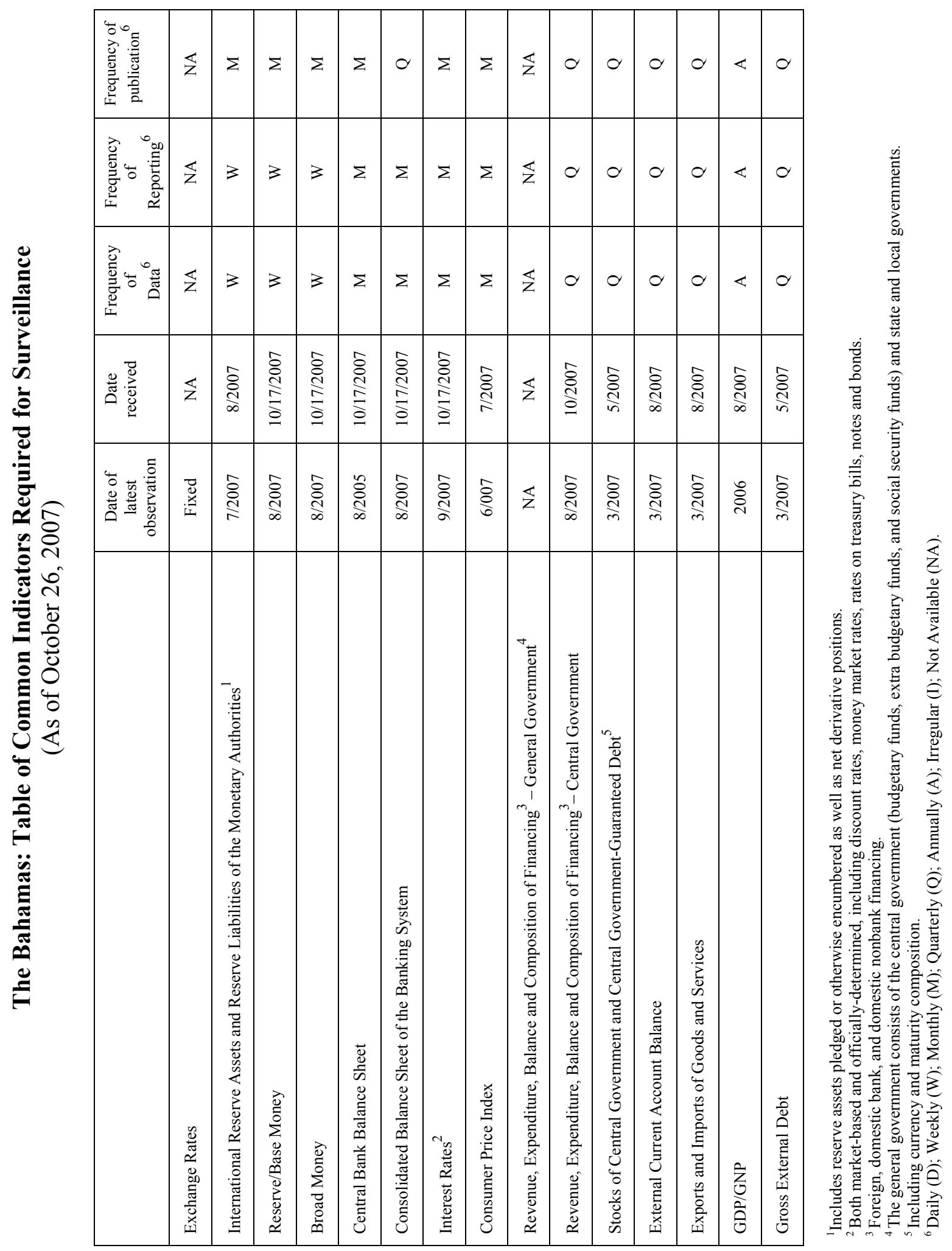




\section{IMF Executive Board Concludes 2007 Article IV Consultation with The Bahamas}

On November 26, 2007, the Executive Board of the International Monetary Fund (IMF) concluded the Article IV consultation with The Bahamas. ${ }^{1}$

\section{Background}

Helped by prudent economic management over the past 30 years, The Bahamas enjoys the third highest per capita GDP among Western Hemisphere countries and social development indicators that compare favorably with other countries in the region. Tourism and related activities account for roughly one-third of Bahamian GDP, and the financial sector, including a dynamic offshore center, account for over 20 percent of GDP.

Macroeconomic performance has been solid. Led by construction on new resort and secondhome projects, the economy grew by close to $3 \frac{1}{2}$ percent in 2006; growth is expected to moderate slightly to 3 percent this year. Inflation remains low at around $2 \frac{1}{2}$ percent. The current account deficit increased sharply to $251 \frac{1}{2}$ percent in 2006, reflecting imports related to the resort investments and higher oil imports. The rise in imports has been largely financed by foreign direct investment but because of a decline in tourist arrivals, there has also been some draw down in international reserves.

\footnotetext{
${ }^{1}$ Under Article IV of the IMF's Articles of Agreement, the IMF holds bilateral discussions with members, usually every year. A staff team visits the country, collects economic and financial information, and discusses with officials the country's economic developments and policies. On return to headquarters, the staff prepares a report, which forms the basis for discussion by the Executive Board. At the conclusion of the discussion, the Managing Director, as Chairman of the Board, summarizes the views of Executive Directors, and this summary is transmitted to the country's authorities.
} 
Macroeconomic policies have been tightened this year. The growth of credit has declined from over 14 percent in 2006 to 10 percent in September in part because of moral suasion by the authorities. In addition, the budget deficit target for FY 2007/08 (ending June 30) is 13/4 percent of GDP compared with a preliminary outturn of about 21/2 percent of GDP in FY 2006/07.

The authorities' see the maintenance of macroeconomic stability and a positive investment climate as the best way to encourage private investment and ensure continued growth in employment and standards of living. Against this background, discussions focused on the economic outlook, policies to maintain macroeconomic stability, and structural reforms to enhance overall efficiency.

\section{Executive Board Assessment}

Executive Directors commended the authorities' solid track record of prudent macroeconomic management, which has helped The Bahamas attain the highest standard of living in the Caribbean. Despite a recent decline in tourist arrivals, macroeconomic performance continues to be favorable, with strong growth, low inflation, and a relatively small fiscal deficit and public debt. The sharp increase in the external current account deficit mainly reflects constructionrelated imports that are financed by foreign direct investment.

At the same time, Directors observed that the external environment poses several challenges and risks going forward, including the relatively slow economic growth projected for the United States next year, a highly competitive regional tourism market, high oil prices, and the country's vulnerability to natural disasters. In this context, they welcomed the authorities' strong commitment to maintaining macroeconomic stability, which is backed by the supportive macroeconomic policy framework in place. Directors also noted that the business climate remains very attractive, and that there is substantial ongoing and planned investment in the tourism sector. In light of this, Directors generally considered that overall The Bahamas' medium-term economic prospects remain favorable. However, Directors reiterated that diversification of both the tourism product and the overall economy will be crucial for strong and sustained economic growth.

Directors supported the government's goals of balancing the budget and reducing debt to 30-35 percent of GDP by 2012. To ensure the achievement of these targets, Directors welcomed the authorities' commitment to control current spending, tighten budget constraints on public entities, and improve tax administration; and they commended the authorities' intention to privatize the telecommunications and electricity companies. Directors welcomed the authorities' plans to streamline import duty and tax concessions, and encouraged the authorities to consider the progressive introduction of a value added tax or a domestic consumption tax to replace trade taxes.

Directors were of the view that the fixed exchange rate has served The Bahamas well, particularly by enhancing the investment climate and keeping inflation low. They welcomed the 
indications that competitiveness is adequate, and noted the strong national consensus in favor of safeguarding the peg.

Directors welcomed the authorities' plans to gradually remove exchange controls. They emphasized that this process will need to be supported by an appropriate macroeconomic policy framework, an adequate level of international reserves, and a strong financial regulatory and prudential framework. In this regard, Directors welcomed the central bank's actions to curb credit growth, both to allow a build-up of international reserves and to reduce the economy's vulnerability to shocks. Directors encouraged the use of market-based monetary policy instruments to improve the effectiveness of monetary policy, make credit allocation more efficient, and help develop the domestic capital market. They supported continued technical assistance from the IMF and the Caribbean Regional Technical Assistance Center to improve the central bank's operational framework.

Directors observed that The Bahamas' financial system remains sound and well regulated. They commended the authorities' efforts to further strengthen the regulatory and supervisory framework and bring it to international standards, including by modernizing the regime to combat money laundering and terrorism financing and introducing a risk-based approach to supervision.

Public Information Notices (PINs) form part of the IMF's efforts to promote transparency of the IMF's views and analysis of economic developments and policies. With the consent of the country (or countries) concerned, PINs are issued after Executive Board discussions of Article IV consultations with member countries, of its surveillance of developments at the regional level, of post-program monitoring, and of ex post assessments of member countries with longer-term program engagements. PINs are also issued after Executive Board discussions of general policy matters, unless otherwise decided by the Executive Board in a particular case. The staff report (use the free Adobe Acrobat Reader to view this pdf file) for the 2007 Article IV Consultation with The Bahamas is also available. 
The Bahamas: Selected Economic Indicators

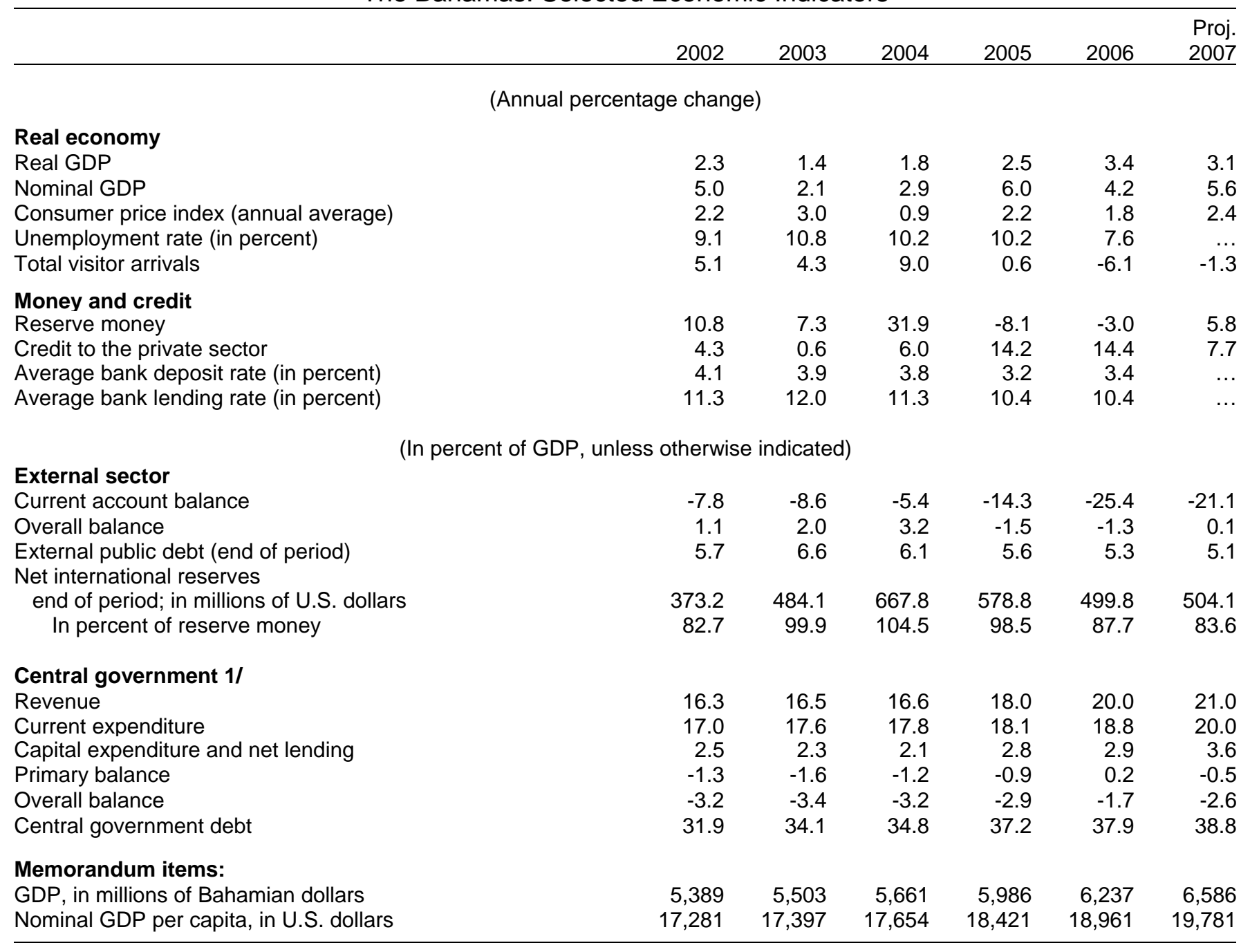

Sources: Central Bank of The Bahamas; Department of Statistics; Ministry of Finance; and IMF staff estimates and projections. 1/ Fiscal year ending June 30. 